\title{
How Well Has the Currency Board Performed? Evidence from Hong Kong*
}

\author{
Yum K. Kwan ${ }^{\mathrm{a}}$ and Francis T. Lui ${ }^{\mathrm{b}}$ \\ ${ }^{a}$ City University of Hong Kong, Tat Chee Avenue, Kowloon, Hong Kong. \\ ${ }^{\mathrm{b}}$ Hong Kong University of Science and Technology, Clear Water Bay, Kowloon, Hong Kong.
}

March 1999

\begin{abstract}
The currency board system has sometimes been identified as the solution to the recent financial turmoil in many countries. Hong Kong, having the experience of abandoning and re-adopting the currency board, offers a natural opportunity to test its macroeconomic implications. We use the method of Blanchard and Quah (1989) to show that the structural equations and the characteristics of permanent and transitory shocks have significantly changed since re-adopting the regime in 1983 . The evidence indicates that its currency board is less susceptible to supply shocks, but demand shocks can create greater volatility. Hong Kong's decent performance is due mainly to the stable fiscal policy. Our analysis shows that two-thirds of the reduction in observed output and inflation volatility are explained by the adoption of the currency board, while the remainders are explained by changes in the external environment. The system does not rule out monetary collapse, however.
\end{abstract}

JEL Classification: E42, E58, F41.

Keywords: Currency board; free floating; dollar peg; monetary regimes; Hong Kong economy.

Corresponding author: Francis T. Lui, Center for Economic Development, Hong Kong University of Science and Technology, Clear Water Bay, Kowloon, Hong Kong. Tel: (+852)-2358-7606, Fax: (+852)-2358-2084, Email: fnfntlui@ust.hk

\footnotetext{
* We thank Barry Eichengreen and Charles Goodhart for helpful and constructive comments on a previous version of this paper. Financial support from the Research Grant Council of Hong Kong, under grant number HKUST6217/97H, is gratefully acknowledged.
} 


\section{INTRODUCTION}

The recent global financial turmoil has changed the currency board from a relatively obscure and unstudied monetary regime to an exchange rate system that has attracted widespread attention. It has been recommended as the definitive solution to stabilize the currency and the economy in Mexico, Indonesia, Russia and Brazil. Part of the enthusiasm may be due to its property of having a stable exchange rate. Its smooth adoption in a number of countries, notably Argentina (1991), Estonia (1992), Lithuania (1994) and Bulgaria (1997) must have also created greater confidence in the system. ${ }^{1}$ If the renewed interest could be sustained and more countries were to adopt currency boards eventually, then as Schwartz (1993) had commented, "a watershed would have been reached in the annals of political economy."

Currency board, first introduced in the British colony of Mauritius in 1849, is a rule-based monetary institution different from a central bank. Although there are variations, a typical currency board has two essential characteristics. First, the board has the obligation to exchange on demand local currency for some major international currency, which is often called the reserve currency, and vice versa, at a fixed exchange rate stipulated in the legislation. Second, local currency is issued based on at least 100 percent reserve of securities denominated mainly in the reserve currency.

Since the nineteenth century, dozens of currency boards had been established in British colonies and other places, often in response to monetary or exchange rate disturbances. ${ }^{2}$ However, when these colonies became independent nations after World War II, most of them decided to replace the currency board with a central bank. Only very few currency boards still survive today. This may be the reason why some people believe that this form of monetary institution has already lost its practical importance. This judgment is premature. Recent events have shown that currency stability is of central importance in policy making in many countries. Currency board is among the few viable options to achieve this end.

Do the benefits of currency board outweigh their costs? This is an important policy question for countries considering to adopt it. Some of the theoretical

1 See Hanke, Jonung and Schuler (1993), Balino et al (1997) and Schuler (1998), among others. 
advantages and disadvantages of currency boards are well known, many of which are the same as those of a commodity-standard monetary system. ${ }^{3}$ For example, convertibility of currency is guaranteed and there is little or no uncertainty about the exchange rate. On the other hand, in times of domestic liquidity crisis, a currency board arrangement cannot act as a lender of last resort. In theory, its reserve currency can only be used to buy local currency or foreign securities. It would be a violation of its basic principle if the reserve were to be used to purchase the assets of a domestic bank suffering from a run. ${ }^{4}$ Moreover, since currency board is a rule-based arrangement, discretionary monetary policies are precluded. Whether this macroeconomic self-discipline is regarded as an advantage, however, is more controversial.

To assess the viability of adopting currency boards as the monetary institution, we should not confine ourselves to theoretical discussions alone. Since they have been in existence for almost one and a half centuries, a more fruitful approach is to analyze rigorously the empirical data generated from actual experience. This literature is generally lacking. In this paper, we shall analyze the macroeconomic implications of a currency board regime using Hong Kong data and methods developed by Blanchard and Quah (1989) and Bayoumi and Eichengreen (1993, 1994). The viability of the regime is also discussed.

In the next section, we shall briefly discuss the institutional background of Hong Kong's currency board and argue why its experience provides us with a unique natural experiment to evaluate some aspects of the system. In Section 3, we shall outline the structural vector autoregressive (VAR) model implemented in this paper.

2 For more detailed discussion of the history of currency boards, see Walters and Hanke (1992), Schwartz (1993), Hanke and Schuler (1994), and Schuler (1998).

3 Williamson (1995) provides a useful summary of the advantages and disadvantages of currency boards.

4 The currency board of Hong Kong is an exception to this rule. There is no formal legislation prohibiting the board from using its foreign reserve to purchase domestic assets, although the board has so far refrained from doing so in a significant way. See the balance sheet in Table 2. One interpretation is that the legislature provides an "escape clause" with which the board can act as a lender of last resort during financial crises. As long as the escape clause is only invoked in truly exceptional and justifiable situations, it will not undermine the credibility of the currency board rule. Bordo and Kydland $(1995,1996)$ interpret the classical gold standard as such kind of contingent monetary rule with an escape clause (i.e., suspension of convertibility). See also footnote 14. It should be noted that when the Hong Kong government spent US\$ 15 billion to buy domestic stocks in August 1998, it was using money from fiscal reserves, but not from the currency board. 
Section 4 presents the quantitative results and their interpretations. Section 5

summarizes some general properties and implications about currency boards that we have learned from the Hong Kong experience.

\section{INSTITUTIONAL BACKGROUND OF HONG KONG'S CURRENCY BOARD}

The currency system of Hong Kong, following that of China, was based on the silver standard in the nineteenth and early part of the twentieth centuries. ${ }^{5}$ In 1934, the United States decided to buy silver at a very high fixed rate and that led to large outflow of silver from Hong Kong and China. ${ }^{6}$ As a result, both governments abandoned the silver standard. In December 1935, Hong Kong enacted the Currency Ordinance, which was later renamed as the Exchange Fund Ordinance, and purchased all privately held silver coins. At the same time, the note-issuing banks, which were private enterprises, had to deposit their silver reserves with the newly created Exchange Fund and received Certificates of Indebtedness (CIs) in return. The Exchange Fund sold the silver in the London market for sterling. From then on, if an authorized bank wanted to issue more notes, it was obligated to purchase more CIs from the Exchange Fund with sterling at a fixed rate of sixteen HK dollar to one pound. The Exchange Fund would also buy the CIs from the banks if the latter decided to decrease the money supply. Thus, the monetary system had all the features of a currency board, with the exception that legal tenders were issued by authorized private banks rather than directly by the board.

The peg to the sterling lasted for more than three decades, despite four years of interruption during World War II. In 1967, because of devaluation of the sterling, the sixteen HK dollar peg could no longer be sustained. In July 1972 further pressure from the devaluation of the sterling forced the eventual abolition of the link between the sterling and HK dollar. The latter was pegged to the US dollar at a rate within an intervention band. This also did not last long. Again devaluation of the US dollar and an inflow of capital to Hong Kong led to the decision of free-floating the HK dollar against the US dollar. The currency board system was no longer operating.

5 For more details on the historical development of the monetary regime in Hong Kong, see Jao (1990), Schwartz (1993), Greenwood (1995) and Nugee (1995).

6 See Friedman and Schwartz (1963, pp. 483 - 491) and Friedman (1992) for the silver-purchase program in 1934 and its deflationary effect on China. 
Under the free-floating system from 1974 to 1983, authorized banks still had to purchase CIs, which at this time were denominated in HK dollar, from the Exchange Fund if they wanted to issue more notes. The Fund maintained an account with these banks. The payment for the CIs was simply a transfer of credit from the banks to the account of the Exchange Fund. Starting from May 1979, the note-issuing banks were required to maintain 100-percent liquid-asset cover against the Fund's short-term deposits. This cover did not imply that the Exchange Fund could effectively limit the creation of money because the banks could borrow foreign currency to obtain the liquid assets. Money growth in this period was higher and more volatile than before. In 1978, the government also decided to transfer the accumulated HK dollar fiscal surplus to the Exchange Fund, which has since then become the government's de facto savings account.

During the initial phase of the free-floating period, the HK dollar was very strong. However, from 1977 onwards, it was subject to considerable downward pressure. Trade deficit was growing. Money supply, M2, increased at the rate of almost 25 percent a year, mainly because of even faster growth in bank credit. The start of the Sino-British negotiations over the future of Hong Kong in 1982 led to a series of financial crises: stock market crash, real estate price collapse, runs of small banks, and rapid depreciation of the HK dollar. On October 17, 1983, the government decided to abolish interest-withholding tax on HK dollar deposits and more importantly, to go back to the currency board system again. The exchange rate was fixed at US\$1 = HK\$ 7.8. Banks issuing notes had to purchase CIs with US dollar at this rate from the Exchange Fund. The reserves accumulated were invested mainly in interest-bearing U.S. government securities. Table 1 summarizes the historical evolution of Hong Kong's monetary institutions.

Insert Table 1 here.

(Exchange rate regimes)

Several new changes to the currency board system of Hong Kong, or now popularly known as the "linked exchange rate system," were introduced. In 1988, the Exchange Fund established the new "Accounting Arrangements" which in effect empowered it to conduct open market operations. Legislative changes also allowed the 
government to have more flexibility in manipulating the interest rates. Since March 1990, the Fund was permitted to issue several kinds of "Exchange Fund Bills," which were similar to short-term Treasury bills. In 1992, a sort of discount window was opened to provide liquidity to banks. The Hong Kong Monetary Authority (HKMA) was established in December 1992 to take over the power of the Exchange Fund Office and the Commissioner of Banking. The HKMA has since then been active in adjusting interbank liquidity in response to changes in demand conditions.

The main instrument used by the HKMA to adjust interbank liquidity is the interest rate. For a long time, it has relied on interest rate arbitrage to stabilize the exchange rate, in the sense that a capital outflow will push up interest rate and consequently lend support to the Hong Kong dollar again. On December 9, 1996, the HKMA introduced a new inter-bank payment system known as the "real time gross settlement" (RTGS). Each bank is required to open an account with positive balance at the HKMA, which can serve as the lubricant for interbank settlements. Because the RTGS has been very efficient, the aggregate balance of the banking system, i.e., the sum of the balances in the individual accounts, tends to be very small, say, at the level of HK\$ 2 billion. However, as discussed in details in Cheng, Kwan and Lui (1999b), the small size of the aggregate balance has caused great interest rate volatility. An outflow of capital exceeding the amount in the aggregate balance may, given the particular institutional arrangements, completely drain the latter and force the interest rate to rise to some exceedingly high level. ${ }^{7}$ Contrary to the belief of the HKMA, the higher interest rate during the financial crisis of 1997-98 was not only harmful to the economy, but also detrimental to the credibility of the exchange rate. It simply signaled the increased risks in holding the Hong Kong dollar (Cheng, Kwan and Lui (1999a)).

Several remarks should be made here. First, the monetary institution in Hong Kong has not been a static system. In less than half a century, it has evolved from the silver standard to a currency board with sterling being the reserve currency, and then to a free-floating regime, and finally back to the currency board with a US dollar link. More recently, as Schwartz (1993) has observed, there has been some "dilution" of the features that distinguish a currency board. Given historical hindsight, one can hardly

7 On October 23, 1997, the overnight interbank rate reached 280 percent. It has often been pointed out that the HKMA might have deliberately pushed up interest rate further by delaying the injection of liquidity back into the economy. See Cheng, Kwan and Lui (1999b). 
believe that the present system will last forever, despite the persistent assurance by the Hong Kong Government that the linked exchange rate is there to stay permanently. This view is supported by the observation that historically all fixed exchange rate regimes could not be sustained for very long periods. ${ }^{8}$ This motivates us to simulate in Section 4.4 the conditions under which the Hong Kong currency board may collapse.

Second, from 1974 to now, Hong Kong has experienced two polar cases of monetary systems, namely, free-floating (1974-83) and currency board (1983-now). There have been no other economic institutional changes of comparable order of magnitude. The government still adopts the "positive non-interventionism" policy formulated more than two decades ago. It has been persistently keeping the size of the government small and leaving small budgetary surpluses in most fiscal years. It has also refrained from using fiscal policy as a fine-tuning tool. The legal system has remained intact and Hong Kong's economic freedom has always been rated at the highest level by international agencies. These similarities in the two periods provide us with a relatively homogeneous setting to compare the implications of the two systems as if under a natural controlled experiment.

Third, while structural homogeneity is needed for the controlled experiment on the one hand, sufficiently rich variations in data are necessary for statistical purpose on the other. If the economic conditions of the two periods had remained perfectly stable, then the data would hardly contain enough information for inferring the macroeconomic performance of the two systems. We need to observe how the two regimes respond to external shocks. Indeed Hong Kong as a small open economy is extremely sensitive to external shocks that may overshadow the "treatment effect" of a currency board system. Fortunately, by adopting the approach in Blanchard and Quah (1989), it is possible to isolate the transitory and permanent shocks during the two periods. Counter-factual simulations can be performed to identify the effects of the change in monetary regime.

Fourth, Hong Kong has gone through a number of major economic shocks from 1974 to now. This period covers the time span of several business cycles. There

8 Eichengreen (1994) casts doubt on the future of any pegged exchange rate regime in the 21st century. He predicts that only the two extremes of flexible exchange rate and monetary union will survive. 
have also been big swings in real estate and stock markets. The quarterly data available are reasonably rich in variations which allow us to make meaningful inferences.

Fifth, the economic health and significant financial strength of Hong Kong provide an almost ideal situation to test the vulnerability of a currency board system when it is confronted with a crisis. At the end of 1997, foreign currency assets in the Exchange Fund amounted to US\$ 75.5 billion, which was the world's third largest. The ratio of foreign currency assets in the Exchange Fund to currency in circulation was bigger than five. The value of the government's accumulated fiscal reserve was also substantial. In fact, it was contributing to one-third of the Exchange Fund (see the Fund's balance sheet in Table 2). If simulations show that Hong Kong's currency board has to face a crisis when it is subject to shocks of specified magnitude, then it is hard to imagine that the currency board in a country with poorer economic health can survive under the same scenario.

Lastly, we do not see the performance of the macroeconomy during the financial crisis of 1997-98 truly representative of the consequence of the currency board. The Hong Kong government at the time had adopted a mechanism that was conducive to excessive interest rate volatility. The problem was remedied in September 1998 when eight technical measures aimed at interest rate stability were introduced by the HKMA. In this paper we have therefore confined our empirical analyses to the period up to the last quarter of 1997, when the effects of the high interest rate policy were not as apparent as in 1998. The readers are referred to Cheng, Kwan and Lui (1999a, 1999b) for detailed discussions of the currency crisis.

Insert Table 2 here.

(Exchange Fund balance sheet)

\section{EMPIRICAL MODEL}

In this Section, we discuss a framework that will be used to compare the macroeconomic performance of the flexible and linked exchange rate regimes when they are subject to exogenous shocks. To properly take into account the heterogeneity 
induced by these shocks, we adopt Blanchard and Quah's (1989) approach to identify them explicitly.

Our empirical framework is the structural vector autoregressive (VAR) model initiated by Blanchard and Watson (1986), Sims (1986), and Bernanke (1986).

Following Blanchard and Quah (1989) and Bayoumi and Eichengreen (1993, 1994), we formulate a bivariate model in output growth and inflation rate to identify two series of structural shocks: (1) those whose effects on output level are only transitory, and (2) those that have permanent effects on the output level. Shocks of the first type can be interpreted as demand shocks originated from innovations in the components of aggregate demand, while the second type are supply shocks originated from innovations in productivity and other factors that affect aggregate supply. We now briefly describe the model and refer the reader to the above references and the surveys in Giannini (1992) and Watson (1994) for details.

Let $X_{t}=\left(\Delta y_{t}, \Delta p_{t}\right)^{\prime}$, where $y_{\mathrm{t}}$ and $p_{\mathrm{t}}$ denote the logarithm of output and price level, respectively, and $\Delta$ is the first-difference operator. $X_{t}$ is assumed to be covariance stationary and have a moving average representation of the form

$$
X_{t}-\mu=B_{0} e_{t}+B_{1} e_{t-1}+B_{2} e_{t-2}+\ldots \equiv B(L) e_{t}
$$

where $e_{\mathrm{t}}=\left(e_{\mathrm{dt}}, e_{\mathrm{st}}\right)^{\prime}$ is a bivariate series of serially uncorrelated shocks with zero mean and covariance matrix $\Omega, B(L)=B_{0}+B_{1} L+B_{2} L^{2}+\ldots$ is a short-hand notation for the matrix polynomial in backshift operator $L$, and $\mu$ is the mean of $X_{t}$. (1) is taken to be structural in that $e_{\mathrm{dt}}$ and $e_{\mathrm{st}}$ have a behavioral interpretation of being the demand shock and supply shock, respectively. The coefficient matrices in $B(L)$ capture the propagation mechanism of the dynamic system. In particular, the $(i, j)$ element of $B_{\mathrm{k}}$ is the $\mathrm{k}$ th step impulse response of the $\mathrm{i}$ th endogenous variables with respect to a one unit increase in the $\mathrm{j}$ th shock.

Equation (1) is not directly estimated. We proceed in the following steps. First, we estimate a VAR in $X_{\mathrm{t}}$ :

$$
A(L)\left(X_{t}-\mu\right)=u_{t}
$$


where $\left\{u_{\mathrm{t}}\right\}$ is a bivariate series of serially uncorrelated errors with zero mean and covariance matrix $\Sigma$, and $A(L)$ is a matrix polynomial in $L$. Second, we invert the estimated autoregressive polynomial in (2) to obtain the Wold moving average representation, which is the reduced form to (1).

$$
X_{t}-\mu=u_{t}+C_{1} u_{t-1}+C_{2} u_{t-2}+\ldots \equiv C(L) u_{t}
$$

Again, $C(L)=I+C_{1} L+C_{2} L^{2}+\ldots$ is short-hand for the matrix polynomial as stated. In our implementation the reduced form VAR is estimated with six lags and the Wold representation in (3) is expanded up to 200 lags which is more than adequate. Given estimates of the reduced form parameters, $C(L)$ and $\Sigma$, and the reduced form residuals $u_{t}$, is it possible to recover the structural parameters, $B(L)$ and $\Omega$, and the structural residuals $e_{\mathrm{t}}$ ? This is a classical identification problem in simultaneous equation models and the answer is yes provided that enough a priori restrictions have been placed on the structural parameters. Comparing (1) and (3) it can be checked that the structural and reduced form are related by the following relationships:

$$
\begin{aligned}
& B_{0} e_{t}=u_{t} \quad \forall t . \\
& B_{j}=C_{j} B_{0}, \quad j=0,1,2, \ldots \\
& B_{0} \Omega B_{0}{ }^{\prime}=\Sigma .
\end{aligned}
$$

Equations (4) and (5) imply that the structural form in (1) can be recovered from the reduced form in (3) once $B_{0}$ is determined. Thus, the identification problem boils down to imposing sufficiently many restrictions so that $B_{0}$ can be solved from (6).

In our bivariate system, there are seven structural parameters in $B_{0}$ and $\Omega$, but only three reduced form parameters in $\Sigma$; we thus need four restrictions to just-identify the structural model. The first three restrictions come from assuming $\Omega$ to be the identity matrix. The zero covariance restriction dictates that the two structural shocks are uncorrelated, implying that any cross-equation interaction of the two shocks on the dependent variables are captured by the lag structure in $B(L)$. The two unit-variance 
restrictions imply that $B_{0}$ is identified up to multiple of the two standard deviations. Thus $B_{\mathrm{j}}$ has the interpretation of being the $\mathrm{j}$ th step impulse response with respect to a one-standard-deviation innovation in the structural shocks. The last restriction comes from Blanchard and Quah's (1989) idea of restricting long-run multiplier. Since demand shocks are assumed to have no permanent effects on output level, this translates into the restriction that the long-run multiplier (i.e., the sum of impulse responses) of demand shocks on output growth must be zero, i.e.,

$$
B_{11}(1) \equiv B_{11,0}+B_{11,1}+B_{11,2}+\ldots=0
$$

where $B_{11}(1)$ and $B_{11, \mathrm{j}}$ are the upper left-hand corner of $B(1)$ and $B_{\mathrm{j}}$ respectively.

To see how (7) can be translated into a restriction on $B_{0}$, let $J$ be the lower triangular Cholesky factor of $\Sigma$ and notice that (6) can be written as (after assuming $\Omega$ = I)

$$
B_{0} B_{0}{ }^{\prime}=\Sigma=J J^{\prime}
$$

Thus $\mathrm{B}_{0}$ can be determined from $J$ up to an orthogonal transformation $S$, i.e.,

$$
B_{0}=J S, \quad S S^{\prime}=I .
$$

Orthogonality implies that $\mathrm{S}$ (up to one column sign change) must be of the form

$$
S=\left[\begin{array}{cc}
a & \sqrt{1-a^{2}} \\
\sqrt{1-a^{2}} & -a
\end{array}\right]
$$

(5) and (9) imply

$$
B(1)=C(1) B_{0}=H S, \quad H=C(1) J
$$

(7) then implies a restriction 


$$
H_{11} a+H_{12} \sqrt{1-a^{2}}=0
$$

which determines a and hence $S$. Once $S$ is found, $B_{0}$ can be determined by (9). Given $B_{0}$, the structural parameters and the structural shocks can then be recovered from the reduced form via (4) and (5).

The output and price data are quarterly Hong Kong real per capita GDP (in 1990 price) and the corresponding GDP deflator from 1973:1 to 1997:4, taken from various issues of Estimates of Gross Domestic Product published by Hong Kong Government. ${ }^{9}$ Both output and price series exhibit strong seasonality and they are deseasonalized before use by a spectral method by Sims (1974) and implemented in Doan (1992, section 11.7). To check our model specification, we perform standard unit root test and cointegration test to the output and price level series. Testing the null hypothesis of I(1) with non-zero drift against the alternative of trend stationarity, the Dickey-Fuller t-statistic register values of -2.14 and -1.47 for the output and price series, respectively, which are way above the $5 \%$ critical value of -3.45 (Hamilton, 1994, Table B6, Case 4). Thus, the covariance stationarity assumption for the firstdifferenced series is warranted. Equation (2) as a first-difference VAR would be invalid if the two series were cointegrated. Testing the null hypothesis of no cointegration, we run cointegrating regressions for the two series and apply augmented Dickey-Fuller (ADF) unit root test to the residuals. With output being the dependent variable in the cointegrating regression, the ADF statistic registers a value of -2.86 , which is above the $5 \%$ critical value of -3.42 (Hamilton, 1994, Table B9, Case 3) and hence not significant. When the price level is instead the dependent variable in the cointegrating regression, the calculated ADF statistic is -2.70 , again not statistically significant at the $5 \%$ level. Thus, we conclude that the output and price level series are not cointegrated and the VAR system in (2) is valid.

\section{RESULTS AND INTERPRETATIONS}

9 Quarterly population figures are obtained by log-linearly interpolating the annual data. 
In this Section, we present the empirical results and interpret them. In particular, we use these results to compare the macroeconomic performance of the free-floating and currency board regimes from several perspectives.

\subsection{INSTITUTIONAL EFFECT OR ENVIRONMENT EFFECT?}

Figures $1 \mathrm{a}$ and $1 \mathrm{~b}$ display the data for the full sample period, covering both the free-floating (1975:1 - 1983:3) and currency board (1983:4 - 1997:4) regimes. It can be seen that both inflation and output growth are somewhat more stable during the currency board years than the free-floating years. More precisely, the standard deviation of output growth rates during the free-floating and currency board years are 2.84 and 2.01, respectively, and that of the inflation rates are 1.56 and 1.18, respectively.

\section{Insert Figures $1 \mathrm{a}$ and $1 \mathrm{~b}$ here.} (output growth and inflation)

What is behind the observed reduction in volatility in both output growth rates and inflation rates? Some believe that this is simply because of a more congenial international environment during the 1980s than the 1970s. On the other hand, advocates of fixed exchange rate and currency board, including the Hong Kong government, sometimes argue that this is due to the inherent superiority of the linked exchange rate regime over the free-floating system (e.g., Sheng, 1995). Granted that both arguments are reasonable and neither can be rejected a priori, it is then necessary to disentangle the "institutional effect" from the "environment effect." In our structural VAR model, the structural parameters, $B_{j}$ 's, play the role of institution and the structural shocks, $u_{t}$, represent the external environment. By estimating two separate structural models for the two exchange rate regimes, we obtain two sets of structural parameters representing the two institutions and two sets of shocks representing two different external environments. We show below that both the parameters and the shocks have changed.

The estimated reduced form, (2) and (3), are not of direct interest and hence not reported. Since the structural model is just identified, there is a one-to-one 
relationship between the reduced form and the structural parameters. This implies that a stability test for the structural equation (1) can be done equivalently by means of the reduced form equation (2). Using this approach, we find that the parameters for the structural equation (1) are indeed statistically different across the two regimes. This is evident from a likelihood-ratio version of the Chow test, which rejects the null hypothesis of no structural change at the 5 percent level. ${ }^{10}$ The result supports the Lucas Critique. We need to use a different set of structural parameters to capture the institutional effect due to a change in the monetary regime. It is assumed, however, that these parameters are invariant to the exogenous shocks.

Figures $2 \mathrm{a}$ and $2 \mathrm{~b}$ present the quarterly demand and supply shocks (1975-97) that are identified by using the econometric framework in Section 3. These shocks are consistent with some well-known historical episodes. For example, the Sino-British negotiations over the future of Hong Kong (1982:4), the government's intervention to suppress housing price (1994:2), and the Asian financial crisis (1997:3 and 4) have created significant negative demand shocks. On the other hand, large supply shocks are apparent during the second oil crisis (1978:3) and the 1989 political events at Tiananmen Square (1989:2).

Table 3 reports the summary statistics of the shocks. By the skewness and kurtosis tests, one can observe that both types of shocks during the free-floating period exhibit substantial non-normality, which can be attributed to a few large negative shocks. The skewness of the shocks can be clearly discerned from their empirical distributions, depicted in Figures $3 a$ and $3 b .{ }^{11}$ Shocks during the currency board period, on the contrary, show no strong evidence against normality, as is clear from the skewness and kurtosis tests and their empirical distributions.

\section{Insert Figures $2 a-b$ and $3 a-b$ here.} (demand and supply shocks; empirical distributions of the shocks) Insert Table 3 here.

$10 \quad$ The likelihood ratio statistic $\mathrm{LR}=-2\left(\ln \mathrm{L}_{0}-\ln \mathrm{L}_{1}-\ln \mathrm{L}_{2}\right)=-2(771.16-291.47-500.49)=41.6$ rejects the null hypothesis of no structural change at the 5 percent level according to a chi-squared distribution with 26 degrees of freedom. $\ln \mathrm{L}_{0}, \ln \mathrm{L}_{1}$, and $\ln \mathrm{L}_{2}$ are the $\log$ likelihood values of the VAR in (2) estimated by using the full sample (75:1 - 97:4), the free float period (75:1 - 83:3), and the currency board period (83:4 - 97:4), respectively.

11 The empirical distribution is obtained by matching the first four sample moments with a GramCharlier expansion. See Johnson and Kotz (1970), p. 15-20. 
This indicates that the two exchange rate regimes are subject to exogenous shocks of different characteristics. Simply comparing the macroeconomic performance in the two periods without properly controlling for the environment effect can be misleading. This forces us to use better methods.

\subsection{VARIANCE DECOMPOSITION AND IMPULSE RESPONSE}

The relative importance of demand and supply shocks changes dramatically across the two exchange rate regimes. This is demonstrated by the results on variance decomposition of the shocks and the estimated values of the impulse responses.

\section{Insert Tables 4 and 5 here.} (variance decompositions for growth rates and levels)

Table 4 shows the percentages of variance in output growth rate and inflation that can be explained by the demand shocks in the last $n$ quarters, where $n$ is the corresponding number in the extreme left column. The percentages explained by the supply shocks are given by 100 minus the table entries. Table 5 is similar to Table 4, but shows the variance in output level and price level explained. As can be readily seen, during the free-floating regime, demand shocks explain a relatively small fraction of the variations in output growth and level, but a substantial fraction of inflation or price movements. ${ }^{12}$ On the other hand, supply shocks can account for most of the output changes, but little of the price fluctuations. In the currency board regime, the results are different. Demand shocks can explain much of the variations in the output and price series, at least in the short run. The movements explained by the supply shocks are also substantial.

\section{Insert Figures $4 a$ and $4 b$ here.}

(Impulse response with respect to demand shocks)

12 The values in the second and third columns of Table 5 decline when $\mathrm{n}$ becomes larger. This is because the variance of output level explained by the demand shocks must converge to zero in the long run. Readers are reminded that in Section 3, we have built in the identifying restriction that demand shocks have no long-term effect on output level. 
The dynamic impulse responses of output and price with respect to demand shocks are consistent with the variance decomposition results above. In Figures 4a and $4 \mathrm{~b}$, the impulse responses, or cumulative effects of a one-standard-deviation demand shock on output and price during the last $\mathrm{n}$ quarters are plotted. The response of output is smaller under the flexible exchange regime. On the other hand, the response of price level under the currency board regime is smaller than that under free-floating.

\section{Insert Figures $5 a$ and $5 b$ here.}

(Impulse response with respect to supply shocks)

Figures $5 \mathrm{a}$ and $5 \mathrm{~b}$ depict the impulse responses of output and price to supply shocks, respectively. The effects of supply shocks on price level across the two regimes are negative, a result consistent with simple economics. The currency board regime seems to be relatively more shock-resistant than the free-floating regime. The impacts of supply shocks on both output and price are smaller during the currency board years.

We can draw the following conclusions from the results above. The output in Hong Kong under a currency board seems to be less susceptible to supply shocks, which are usually not induced by government short-term policies. However, demand shocks do cause greater short-term volatility in output under the currency board system. If a government with a currency board is able to discipline itself to pursue a stable and predictable fiscal policy, the volatility of the economy may be lower than that under free-floating. An explanation of why Hong Kong's economy has been less volatile after the adoption of the linked exchange rate is that stable fiscal policy has, at least until recently, been the philosophy of the financial branch of its government.

\subsection{COUNTER-FACTUAL SIMULATIONS}

As discussed in Section 4.1, the two periods under consideration are subject to shocks with different properties. One way to compare the performance of the two regimes is to consider the following two counter-factual cases: 
Case 1: What would have happened to the economy if the currency board system were adopted from 1975 to 1983 ?

Case 2: What would have happened to the economy if the free-floating system were adopted from 1983 to 1997 ?

To answer the question in Case 1, we apply the demand and supply shocks of 1975 to 1983 to equation (1) which has been estimated for the currency board regime, and compare the simulated results with the actual time path. To answer the second question, we do the simulations in a similar way, but this time we apply the shocks of 1983 to 1997 to equation (1) for the free-floating regime. The approach is based on the assumption that the supply and demand shocks identified in the estimation procedure of Section 3 are invariant to the changes in exchange rate regime. This exogeneity assumption makes a lot of sense for Hong Kong. In this small open economy whose external sector is much larger than its GDP, most of the supply and demand shocks are external. The government has been following the same stable fiscal policy throughout the two periods under consideration. Moreover, there is no central bank in Hong Kong to determine the money supply, which is largely rule-based in both regimes and automatically adjusts to external shocks. Thus, there is no a priori reason to believe that the supply and demand shocks are regime dependent.

The counter-factual exercise amounts to replacing the structural residual $e_{t}$ in equation (1) by a hypothetical residual $e_{t}^{*}$ and then simulating a new data path $X_{t}^{*}$, given structural parameters $\mu$ and $B(L)$. For example, in Case $1, e_{t}, \mu$, and $B(L)$ are the residual and structural parameters for the free-floating regime, while $e_{t} *$ is taken to be the residual for the currency board regime. In practice, however, the moving average representation in equation (1) is difficult to work with. We instead perform the simulation by equation (2) with a reduced form residual $u_{t} *$ constructed from $e_{t} *$ via equation (4). It is straightforward to check that our two-step procedure is equivalent to a direct simulation of equation (1).

\section{Insert Table 6 here.}

(Counter-factual simulation)

Insert Figures $6 a$ and $6 b$ here.

(Output and price level: 1975 - 83)

Insert Figures $7 a$ and $7 b$ here.

(Output and price level: 1983 -97) 
Summaries of these counter-factual simulations are presented in Table 6. The results show that if the currency board system were adopted in the first period, then the average growth rate would have declined, but inflation would have gone down also. Since the standard deviations are also lower, we can say that both output growth and inflation would have been more stable. The patterns for the second period are similar. The cost of a currency board system is lower output growth. However, there are also benefits. Inflation rate decreases and the economy is less volatile. The tradeoff is transparent when the comparison is in terms of levels (rather than growth rates) as depicted in Figures 6a, b, and 7a, b.

The counter-factual simulations disentangle the effects of regime shift and changes in the external environment. As an example, consider the reduction in output growth volatility when the monetary system changes from free-floating to currency board. The standard deviation of output growth rates goes down from 2.84 to 2.01, a roughly 29 percent reduction in volatility. From simulation case 1, we see that if the currency board system were adopted to the environment of the 1970s, output volatility would have declined to 2.26 , a 20 percent reduction from 2.84 . This implies that about 69 percent of the reduction in output volatility that we actually observe from the data is due to the adoption of the currency board, while the remaining 31 percent is due to a more tranquil external environment in the 1980s. Similarly, the marginal effect of the currency board on inflation volatility is to reduce it from 1.56 to 1.30, or about 17 percent reduction. The observed reduction, however, is from 1.56 to 1.18 , or a decline of 24 percent. One can then have the following decomposition. The difference in external environment during the 1970s and 1980s accounts for 29 percent of the reduction in inflation volatility, while the change in the monetary regime explains the remaining 70 percent of the reduction.

\subsection{CURRENCY AND BANKING CRISES}

The Hong Kong government has been vehemently claiming that the Exchange Fund is financially strong and the linked exchange rate will be defended. As can be seen from the balance sheet of the Fund in Table 2, Hong Kong indeed owns one of

the largest foreign reserves in the world. Does it mean that the HK\$ 7.8 link is immune 
of the possibility of crisis? In theory, a crisis does not occur even when people exchange all the currency for foreign assets because of the 100 percent back-up. However, we should note that foreign reserves are enough only to provide partial support to M3. Take the end of 1997, when speculative attacks occurred, as an illustrative example. Total M3 was HK\$ 2827 billion, 41 percent of which was in bank deposits denominated in foreign money. ${ }^{13}$ Suppose people decided to change the portfolio of M3 by exchanging HK dollar deposits for foreign money. If the change were big enough, the banking sector would have to sell its domestic assets for foreign money to avoid bank runs. It is not clear whether the Fund would be willing to buy these domestic assets. However, the Exchange Fund Ordinance would allow the Financial Secretary the flexibility to do so even though Hong Kong's monetary institution had been a currency board. ${ }^{14}$ Suppose the Exchange Fund would indeed provide the foreign liquidity to avoid bank runs. If people decided to increase their foreign exchange holdings from 41 percent to 48 percent of $\mathrm{M} 3$, the accumulated earnings in the balance sheet of the Fund would disappear. If the foreign deposits ratio went up further to 56 percent, all the fiscal reserve would be used up.

These rather simplistic calculations tell us that a run on the Hong Kong dollar could occur even though the change in people's portfolio holdings is not exceptionally big. We do not have an estimate of the portfolio holdings as a function of other variables. However, one can reasonably speculate that the confidence in the HK dollar will suffer significantly and the link will face a crisis if the fiscal reserve is completely depleted.

The amount of fiscal reserve is affected by shocks to the economy. Since the Hong Kong government, until recently, has been following a reasonably stable fiscal policy, we focus our attention on supply shocks here. How big are the supply shocks if the fiscal reserve is to be eliminated? This can be answered by making use of the empirical estimates in this paper.

\footnotetext{
$13 \quad$ Hong Kong Monetary Authority (1998).
}

14 The Exchange Fund Ordinance, Section 3 (2), states that "The Fund, or any part of it, may be held in Hong Kong currency or in foreign exchange or in gold or in silver or may be invested by the Financial Secretary in such securities or other assets as he, after having consulted the Exchange Fund Advisory Committee, considers appropriate." (Hong Kong Monetary Authority (1994), p. 51). See also footnote 4 . 
The long-run impulse response of the logarithm of $y(t)$ with respect to a supply shock of one standard deviation is 0.0141 . This means that a one-standard-deviation supply shock will reduce output permanently by 1.41 percent, other things being equal. Thus, we can calculate the post-shock output level $y(t)^{*}$ by the formula $y(t)^{*}=(1-$ $0.0141 \mathrm{x}) \mathrm{y}(\mathrm{t})$ for a supply shock of size $\mathrm{x}$ standard deviations. Similarly for K periods of negative supply shocks, each of size $\mathrm{x}$, the post-shock output level should be $\mathrm{y}(\mathrm{t})^{*}=$ $(1-0.0141 \mathrm{x})^{\mathrm{K}} \mathrm{y}(\mathrm{t})$. Table 7 reports the expenditure and revenue (as percentages of GDP) of the Hong Kong government from 1982 to 1997. It can be seen that the government has managed to achieve small budget surplus in most years and the average expenditure and revenue rates are $16.7 \%$ and $16.9 \%$, respectively. Suppose the Hong Kong government is to maintain her traditional fiscal restraint, we may assume that the expenditure and revenue rates are to be fixed at the mentioned longterm average values. Then the post-shock revenue would be $0.169 \mathrm{y}(\mathrm{t})^{*}=[0.169(1-$ $\left.0.0141 \mathrm{x})^{\mathrm{K}}\right] \mathrm{y}(\mathrm{t})$. Thus, the effect of the supply shock on revenue is equivalent to a "taxcut" with the new, effective tax rate being $0.169(1-0.0141 \mathrm{x})^{\mathrm{K}}$. These rates are shown in Table 8. Making use of Table 8, one can come up with results in different scenarios. For example, it only takes a 2-standard-deviation shock lasting for one quarter to throw the budget into deficit. If there are negative 3-standard-deviation supply shocks lasting for two years, then the deficit every year will be approximately HK\$ 51.6 billion. It only takes about three years for the fiscal reserve to be completely depleted if political pressures prohibit the government from reducing its expenditures accordingly. In fact, the recession in 1998 has already created a budget deficit of around HK \$35 for that year, and it is projected that there will be another budget deficit of similar size in 1999. Thus, there is a chance that stability of the currency board will be tested again in the future.

Insert Table 7 here.

(Expenditure and revenue of Hong Kong government)

Insert Table 8 here. (Post-shock revenue-output ratio \%)

Currency crises can lead to bank runs. But bank runs can occur because of other reasons too. Since the typical currency board does not provide a lender of last 
resort, bank runs are often regarded as the Achilles Heel of the system. Indeed banking crises did occur in Hong Kong a number of times, all during the currency board years. The government and the banking system resorted to several ways to deal with them.

In 1994 there were 180 licensed banks in Hong Kong, 16 of which were owned mostly by local shareholders (Hong Kong Monetary Authority, 1994, p. 90-91). Government policies towards runs on local and foreign banks seemed to be different. It did not attempt to support the Citibank in 1991 when rumors caused a short-lived run, nor did it try to rescue the Bank of Credit and Commerce International's Hong Kong branch before its collapse in the same year. However, it moved to take over two small local banks in the mid 1960s and three more in the period of 1982-86. It also provided some emergency funds to support five banks in the same period, four of which were later acquired by others. The note-issuing banks also played an important role in cushioning the shocks from the runs. They supported one bank in 1961, three in 196566 , and took over three more in the same period. Thus, in the 1960s, the government was relying mainly on the financially strong note-issuing banks to either lend to or take over the troubled local banks. In more recent years, the government seemed to have resorted to the Exchange Fund for playing the role of lender of last resort. ${ }^{15}$ This is another reason to say that some of the features of a currency board have been diluted in Hong Kong.

\section{WHAT CAN WE LEARN FROM HONG KONG'S EXPERIENCE?}

The general performance of the currency board in Hong Kong has been good in the sense that it has contributed to greater stability. Counter-factual exercises indicate that when both free-floating and currency board regimes are subject to the same exogenous shocks, output and prices are less volatile under the latter.

The stability result is not general. Simulations on impulse response show that output is less sensitive to supply shocks under currency board than under free-floating. On the other hand, demand shocks can cause stronger short-term volatility in output in a currency board system. The relative stability in output in Hong Kong to a large extent must have come from the government's self-discipline in fiscal policy, which is

15 See Jao (1993, Chap. 13) and Ho et al (1991, Chap.1) for more details about banking crises in Hong Kong. 
based on two rules: balanced budget or small surplus, and keeping government size small. Other countries without a stable rule-based fiscal policy may not do well to reduce output volatility even if they have currency boards. ${ }^{16}$

The fiscal restraint not only affects output stability, but also the credibility of the exchange rate system. A weakness of the currency board system is that people may doubt the determination and capability of the government to maintain perfect convertibility at the specified rate. The conservative fiscal policy has been instrumental in creating surpluses for almost every budgetary year. Without the significant fiscal reserve, confidence in the Hong Kong dollar may suffer. In recent years, since the Exchange Fund has been acting as if it could be the lender of last resort, its financial strength, which is partly supported by a large fiscal reserve, is all the more important. Perhaps a reason why fiscal policy in Hong Kong is coordinated with its monetary system is that the Financial Secretary has the authority to control both.

Despite the financial strength of the Exchange Fund, the Hong Kong dollar has for several times been subject to considerable speculative pressure, especially during the Asian financial turmoil. In each occasion, the forward rate of the Hong Kong dollar has depreciated, although the spot rate remains relatively robust. Do people have enough confidence in the Hong Kong dollar? Typically more than 40 percent of M3 is in deposits denominated in foreign currency. This large portion is an indication that people only have limited confidence in the future of the Hong Kong dollar, in spite of all the assurance that the government has provided.

Should other countries adopt the currency board system? The above analysis indicates that the decent performance in Hong Kong has been due to a combination of favorable factors, and yet, the possibility of monetary collapse cannot be ruled out. It is doubtful that many countries have equal or better conditions.

16 The Financial Secretary of Hong Kong once articulated his commitment to the non-interventionist rule-based fiscal policy by referring to a story in Greek mythology. The half-bird half-woman Sirens sang so beautifully that all sailors who heard them would dive into the sea and try to swim to them, only to drown and die at their feet. He said that he would tie himself to the mast of the ship when he heard them singing. See Tsang (1995). 


\section{REFERENCES}

Balino, T., C. Enoch, A. Ize, V. Santiprabhob, and P. Stella, "Currency board arrangements: Issues and experiences,” IMF Occasional Paper 151, 1997.

Bayoumi, T. and B. Eichengreen, "Shocking aspects of European monetary integration," in F. Torres and F. Giavazzi, eds., Adjustment and Growth in the European Monetary Union (Cambridge University Press, 1993).

, "Macroeconomic adjustment under Bretton Woods and the post-BrettonWoods float: An impulse response analysis," Economic Journal 104 (1994), 813-827.

Bernanke, B., "Alternative explanations of the money-income correlation," Carnegie Rochester Conference Series on Public Policy 25 (1986), 49-99.

Blanchard, O. J. and M. Watson, "Are business cycles all alike?" in R. Gordon, ed., The American Business Cycle: Continuity and Change (University of Chicago Press, 1986).

Blanchard, O. J. and D. Quah, "The dynamic effects of aggregate demand and supply disturbances," American Economic Review 79 (1989), 655-673.

Bordo, M. and F. Kydland, "The gold standard as a rule: An essay in exploration," Explorations in Economic History 32 (1995), 423-464.

, "The gold standard as a commitment mechanism," in T. Bayoumi, B. Eichengreen and M. Taylor, eds., Modern Perspectives on the Gold Standard (Cambridge University Press, 1996).

Doan, T., RATS User's Manual Version 4 (Estima, 1992).

Cheng, L. K., Kwan, Y. K., and Lui, F. T. (a), "Risk premium, currency board, and attacks on the Hong Kong dollar," paper presented at the American Economic Association Meetings, January 3, 1999, New York.

(b), "An alternative approach to defending the Hong Kong dollar," paper presented at the American Economic Association/Chinese Economists Society Joint Session, January 4, 1999, New York.

Eichengreen, B., International Monetary Arrangements for the 21st Century (The Brookings Institution, 1994).

Friedman, M. and A. J. Schwartz, A Monetary History of the United States: 18671960 (Princeton University Press, 1963).

Friedman, M., "Franklin D. Roosevelt, silver, and China," Journal of Political Economy 100 (1992), 62-83. 
Giannini, C., Topics in Structural VAR Econometrics (Springer-Verlag, 1992).

Greenwood, J., "The debate on the optimum monetary system," Asian Monetary Monitor 19 (1995), 1-5.

Hamilton, J., Time Series Analysis (Princeton University Press, 1994).

Hanke, S. H., L. Jonung, and K. Schuler, Russian Currency and Finance: A Currency Board Approach to Reform (Routledge, 1993).

Hanke, S. H. and K. Schuler, Currency Boards for Developing Countries (Institute for Contemporary Studies Press, 1994).

Ho, R.Y.K., R. Scott, and K. A. Wong, The Hong Kong Financial System (Oxford University Press, 1991).

Hong Kong Census and Statistics Department. Estimates of Gross Domestic Product 1961 to 1995 (Hong Kong Government Printer, 1995).

Hong Kong Monetary Authority. Annual Report (Hong Kong Monetary Authority, 1994, 1995).

, Monthly Statistical Bulletin, September issue (Hong Kong Monetary Authority, 1998).

Jao, Y. C., "From sterling exchange standard to dollar exchange standard: The evolution of Hong Kong's contemporary monetary system 1967-89," in Y.C. Jao and F. King, eds., Money in Hong Kong: Historical Perspective and Contemporary Analysis (University of Hong Kong Press, 1990).

Jao, Y. C. Hong Kong's Financial System Towards the Future (Joint Publishing Company, 1993).

Johnson, N. L. and S. Kotz, Distributions in Statistics -- Continuous Univariate Distribution 1 (John Wiley \& Sons, 1970).

Kendall, M.G. and A. Stuart, The Advanced Theory of Statistics Vol. 1 (C. Griffin \& Company, 1958).

Nugee, J., "A brief history of the exchange fund," in Money and Banking in Hong Kong (Hong Kong Monetary Authority, 1995).

Schuler, K., “Currency boards,” http://www.erols.com/kurrency, 1998.

Schwartz, A. J., "Currency boards: Their past, present and possible future role," Carnegie-Rochester Conference Series on Public Policy 39 (1993), 147-187. 
Sheng, A., "The Linked Exchange Rate System: Review and Prospects," Hong Kong Monetary Authority Quarterly Bulletin (1995), 54-61.

Sims, C. A., "Seasonality in regression," Journal of the American Statistical Association 69 (1974), 618-626.

Sims, C. A., "Are forecasting models usable for policy analysis?" Federal Reserve Bank of Minneapolis Quarterly Review 10 (1986), 2-16.

Tsang, D., "Looking Downwards From the Olympics," Ming Pao (October, 1995, in Chinese).

Walters, A. A. and S. Hanke, "Currency boards," in P. Newman, M. Milgate and J. Eatwell, eds., The New Palgrave Dictionary of Money and Finance (Macmillan, 1992).

Watson, M., "Vector autoregression and cointegration," in R. Engle and D. McFadden, eds., Handbook of Econometrics Vol. 4 (Elsevier, 1994).

Williamson, J. What Role for Currency Boards? (Institute for International Economics, 1995).

Table 1 The exchange rate regimes for the Hong Kong dollar

\begin{tabular}{|c|c|c|}
\hline Date & Exchange rate regime & Reference rate \\
\hline Until 4 Nov 1935 & Silver standard & - \\
\hline 6 Dec 1935 & \multirow[t]{2}{*}{ Pegged to Sterling } & $£ 1=\mathrm{HK} \$ 16$ \\
\hline 23 Nov 1967 & & $£ 1=\mathrm{HK} \$ 14.55$ \\
\hline 6 July 1972 & \multirow{2}{*}{$\begin{array}{l}\text { Fixed to US dollar with } \pm 2.25 \% \\
\text { intervention bands around a } \\
\text { central rate }\end{array}$} & $\mathrm{US} \$ 1=\mathrm{HK} \$ 5.65$ \\
\hline 14 Feb 1973 & & $\mathrm{US} \$ 1=\mathrm{HK} \$ 5.085$ \\
\hline 25 Nov 1974 & Free float & - \\
\hline 17 Oct 1983 & Pegged to US dollar & $\mathrm{US} \$ 1=\mathrm{HK} \$ 7.80$ \\
\hline
\end{tabular}

Source: Nugee (1995). 
Table 2 Exchange Fund Balance Sheet

\begin{tabular}{|c|c|c|c|c|c|c|c|}
\hline $\mathrm{HK} \$ \mathrm{mn}$ & 1989 & 1990 & 1991 & 1992 & 1993 & 1994 & 199 \\
\hline \multicolumn{8}{|l|}{ ASSETS } \\
\hline Foreign currency assets & 149,152 & 192,323 & 225,333 & 274,948 & 335,499 & 381,233 & 428,54 \\
\hline \multirow[t]{2}{*}{ Hong Kong dollar assets } & 9,625 & 3,874 & 10,788 & 12,546 & 12,987 & 24,617 & 32,18 \\
\hline & 158,777 & 196,197 & 236,121 & 287,494 & 348,486 & 405,850 & 460,73 \\
\hline \multicolumn{8}{|l|}{ LIABILITIES } \\
\hline Certificate of Indebtedness & 37,191 & 40,791 & 46,410 & 58,130 & 68,801 & 74,301 & 77,60 \\
\hline Fiscal Reserve Account & 52,546 & 63,226 & 69,802 & 96,145 & 115,683 & 131,240 & 125,91 \\
\hline Coins in circulation & 2,012 & 2,003 & 2,299 & 2,559 & 2,604 & 3,372 & 3,59 \\
\hline Exchange Fund Bills and Notes & 0 & 6,671 & 13,624 & 19,324 & 25,157 & 46,140 & 53,12 \\
\hline Balance of banking system & 978 & 480 & 500 & 1,480 & 1,385 & 2,208 & 1,76 \\
\hline \multirow{2}{*}{ Other liabilities } & 1,603 & 391 & 4,834 & 3,220 & 7,314 & 22,815 & 38,60 \\
\hline & 94,330 & 113,562 & 137,469 & 180,858 & 220,944 & 280,076 & 300,60 \\
\hline ACCUMULATED EARNINGS & 64,447 & 82,635 & 98,652 & 106,636 & 127,542 & 125,774 & 160,13 \\
\hline
\end{tabular}

Source: Hong Kong Monetary Authority Annual Report, various issues 
Table 3

Characteristics of structural disturbances

\begin{tabular}{|c|c|c|c|c|}
\hline & \multicolumn{2}{|c|}{ Demand shocks } & \multicolumn{2}{|c|}{ Supply shocks } \\
\hline & Free-floating & Currency Board & Free-floating & Currency Board \\
\hline Skewness & $-0.91 \quad[0.01]$ & $\begin{array}{ll}-0.04 & {[0.89]} \\
\end{array}$ & $\begin{array}{ll}-0.76 & {[0.04]}\end{array}$ & $\begin{array}{ll}0.15 & {[0.63]}\end{array}$ \\
\hline Kurtosis & {$[0.11]$} & {$[0.37]$} & $4.74[0.02]$ & {$[0.09]$} \\
\hline Maximum & 1.81 & 2.49 & 2.24 & 3.09 \\
\hline Minimum & -3.01 & -2.44 & -3.07 & -2.42 \\
\hline
\end{tabular}

- Skewness $\left(b_{1}{ }^{1 / 2}\right)=\mathrm{m}_{3} / \mathrm{m}_{2}{ }^{3 / 2}$ and Kurtosis $\left(\mathrm{b}_{2}\right)=\mathrm{m}_{4} / \mathrm{m}_{2}{ }^{2} . \mathrm{m}_{\mathrm{k}}$ is the $\mathrm{k}$ th sample moment around mean.

- $\quad$ Numbers in squared brackets are p-values for testing either the population skewness $=0$ (symmetry) or kurtosis $=3$ (normal shape).

- For testing symmetry, Fisher's test statistic $\xi=x\left(1+3 / n+91 / 4 n^{2}\right)-(3 / 2 n)(1-111 / 2 n)\left(x^{3}-3 x\right)-$ $\left(33 / 8 n^{2}\right)\left(x^{5}-10 x^{3}+15 x\right)$ is approximately distributed as $\mathrm{N}(0,1)$ under the null hypothesis, where $\mathrm{x}$ $=\mathrm{b}_{1}{ }^{1 / 2}(\mathrm{n}-1) /(6(\mathrm{n}-2))^{1 / 2}$, and $\mathrm{n}$ is the sample size. The approximate normality is very accurate even in small sample, see Kendall and Stuart (1958) p.298.

- For testing kurtosis $=3$, the test statistic $\mathrm{z}=\mathrm{y}[(\mathrm{n}-1)(\mathrm{n}-2)(\mathrm{n}-3) / 24 \mathrm{n}(\mathrm{n}+1)]^{1 / 2}$ is approximately distributed as $\mathrm{N}(0,1)$ under the null hypothesis, where $\mathrm{y}=\left[\mathrm{n}^{2} /(\mathrm{n}-1)(\mathrm{n}-2)(\mathrm{n}-3)\right]\left[(\mathrm{n}+1) m_{4}-3(\mathrm{n}-\right.$ 1) $\left.\mathrm{m}_{2}^{2}\right] / \mathrm{s}^{4}$, and $\mathrm{s}$ is the sample standard deviation (with divisor $\mathrm{n}-1$ ). See Kendall and Stuart (1958) p.305-306.

Table 4 Percentage of forecast error variance explained by demand shocks

\begin{tabular}{|l|l|l|l|l|}
\hline & \multicolumn{2}{|c|}{ Output growth rate } & \multicolumn{2}{c|}{ Inflation rate } \\
\hline Quarter & Free-floating & Currency Board & Free-floating & Currency Board \\
\hline 1 & 1.35 & 15.56 & 92.02 & 62.28 \\
4 & 7.06 & 16.36 & 90.12 & 64.60 \\
8 & 7.87 & 18.81 & 84.14 & 62.19 \\
12 & 8.54 & 19.26 & 84.73 & 61.03 \\
16 & 8.64 & 19.39 & 84.40 & 59.87 \\
20 & 8.65 & 19.33 & 84.45 & 59.38 \\
24 & 8.66 & 19.33 & 84.41 & 59.12 \\
28 & 8.67 & 19.33 & 84.40 & 58.97 \\
32 & 8.67 & 19.32 & 84.40 & 58.89 \\
\hline
\end{tabular}

- The corresponding percentages explained by supply shocks are given by 100 minus the table entries

Table 5 Percentage of forecast error variance explained by demand shocks

\begin{tabular}{|l|l|l|l|l|}
\hline & \multicolumn{2}{|c|}{ Output level } & \multicolumn{2}{c|}{ Price level } \\
\hline Quarter & Free-floating & Currency Board & Free-floating & Currency Board \\
\hline 1 & 0.018 & 3.28 & 99.25 & 73.16 \\
4 & 0.368 & 10.76 & 99.97 & 99.07 \\
8 & 0.207 & 4.27 & 99.73 & 99.89 \\
12 & 0.093 & 2.52 & 98.79 & 99.95 \\
16 & 0.047 & 1.55 & 97.85 & 99.97 \\
20 & 0.028 & 1.01 & 97.55 & 99.98 \\
24 & 0.019 & 0.71 & 97.26 & 99.98 \\
28 & 0.013 & 0.53 & 96.88 & 99.99 \\
32 & 0.010 & 0.41 & 96.61 & 99.99 \\
\hline
\end{tabular}

- The corresponding percentages explained by supply shocks are given by 100 minus the table entries 
Table 6

Counter-factual simulation

\begin{tabular}{|l|l|l|l|l|}
\hline & \multicolumn{2}{|c|}{ Output growth rate \% } & \multicolumn{2}{c|}{ Inflation rate \% } \\
\cline { 2 - 5 } & Mean & Standard dev. & Mean & Standard dev. \\
\cline { 1 - 4 } Case 1 (1975-83) & & & & \\
\cline { 1 - 5 } Actual (FF) & 1.54 & 2.84 & 2.13 & 1.56 \\
Simulated (CB) & 0.98 & 2.26 & 1.65 & 1.30 \\
\hline Case2 (1983-97) & & & & \\
\cline { 1 - 5 } Actual (CB) & 1.04 & 2.01 & 1.80 & 1.18 \\
Simulated (FF) & 1.59 & 2.62 & 2.22 & 1.33 \\
\hline
\end{tabular}

- $\mathrm{CB}=$ currency board

- $\quad \mathrm{FF}=$ free floating

Table 7 Expenditure and revenue (as \% of GDP)

\begin{tabular}{|l|l|l|}
\hline Year & Expenditure & Revenue \\
\hline 1982 & 19.2 & 16.7 \\
1983 & 18.6 & 14.7 \\
1984 & 16.0 & 15.5 \\
1985 & 16.6 & 16.7 \\
1986 & 15.9 & 16.1 \\
1987 & 14.5 & 16.5 \\
1988 & 14.9 & 16.7 \\
1989 & 16.4 & 16.5 \\
1990 & 16.3 & 15.3 \\
1991 & 16.2 & 17.1 \\
1992 & 15.8 & 17.3 \\
1993 & 17.3 & 18.6 \\
1994 & 16.3 & 17.2 \\
1995 & 17.8 & 16.7 \\
1996 & 17.7 & 17.5 \\
1997 & 18.4 & 20.7 \\
Mean & 16.7 & 16.9 \\
\hline
\end{tabular}

Table 8 Post-shock effective revenue-output ratio \%

\begin{tabular}{|c|c|c|c|c|}
\hline & \multicolumn{4}{|c|}{$\begin{array}{c}\text { size of negative supply shocks } \\
\text { (in standard deviation) }\end{array}$} \\
\hline Duration (quarters) & 1 & 2 & 3 & 4 \\
\hline 1 & 16.7 & 16.4 & 16.2 & 15.9 \\
2 & 16.4 & 16.0 & 15.5 & 15.0 \\
3 & 16.2 & 15.5 & 14.8 & 14.2 \\
4 & 16.0 & 15.1 & 14.2 & 13.4 \\
5 & 15.7 & 14.6 & 13.6 & 12.6 \\
6 & 15.5 & 14.2 & 13.0 & 11.9 \\
7 & 15.3 & 13.8 & 12.5 & 11.3 \\
8 & 15.1 & 13.4 & 12.0 & 10.6 \\
\hline
\end{tabular}




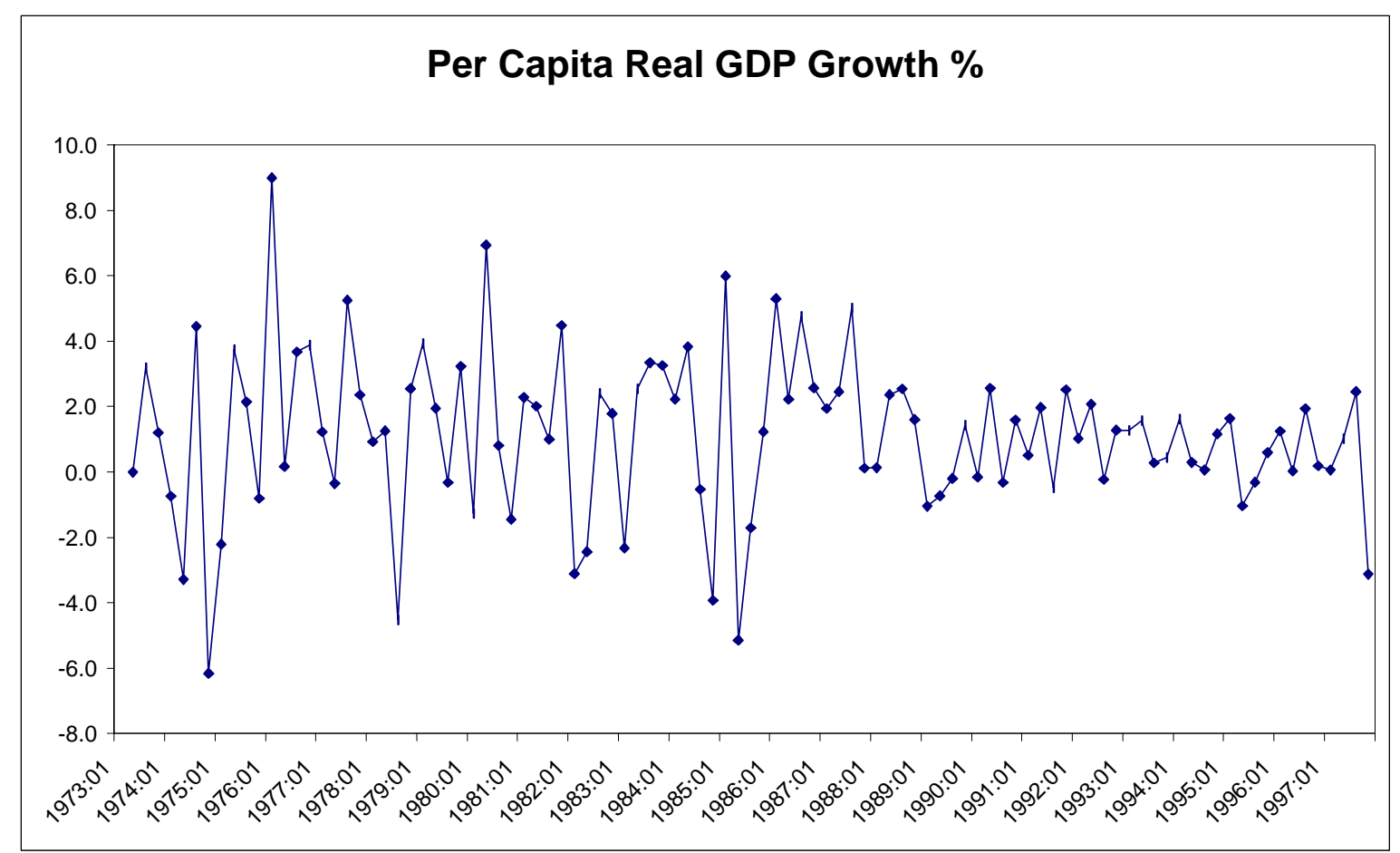

Figure 1a

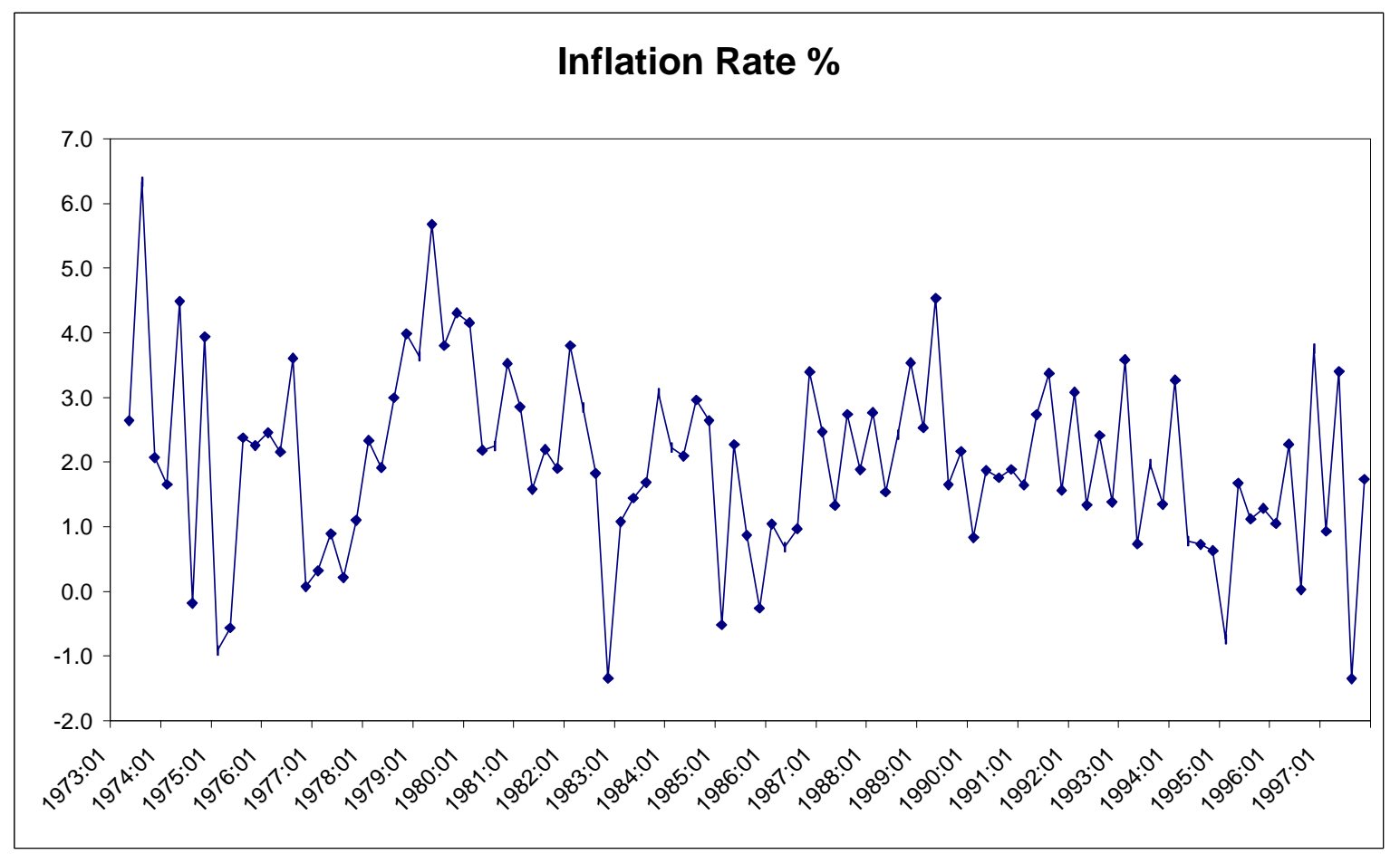

Figure 1b 


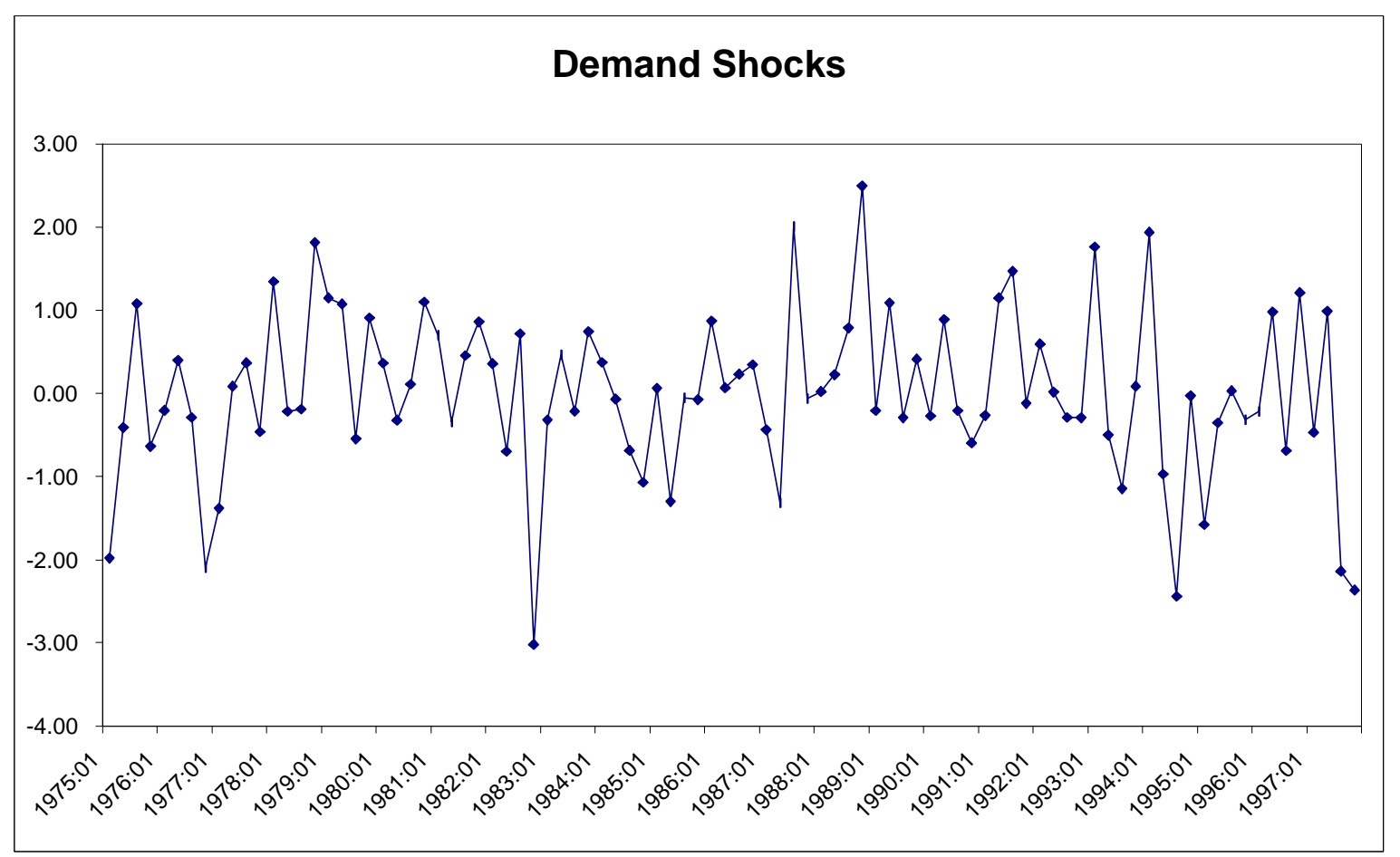

Figure 2a

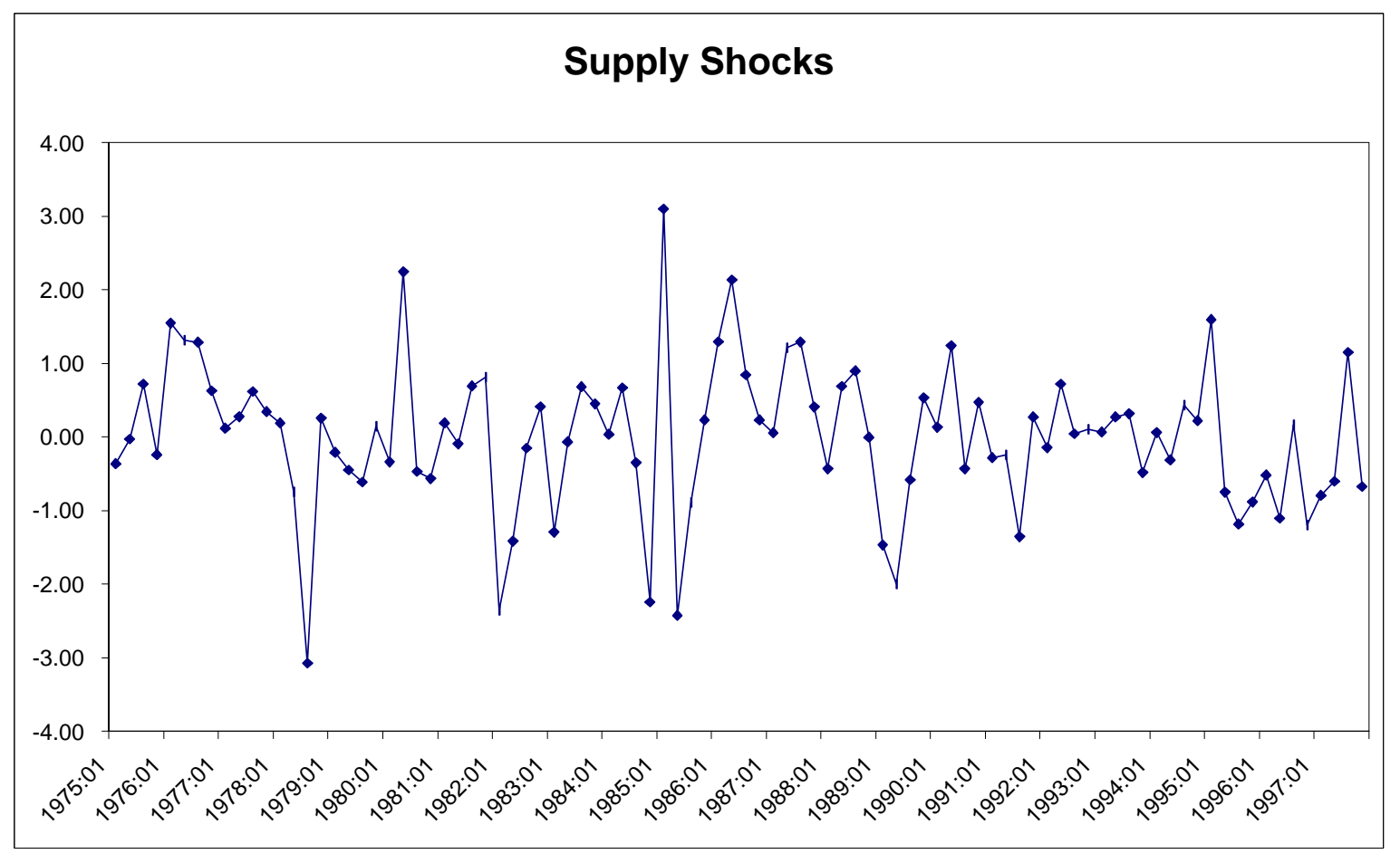

Figure 2b 
Density function of demand shocks

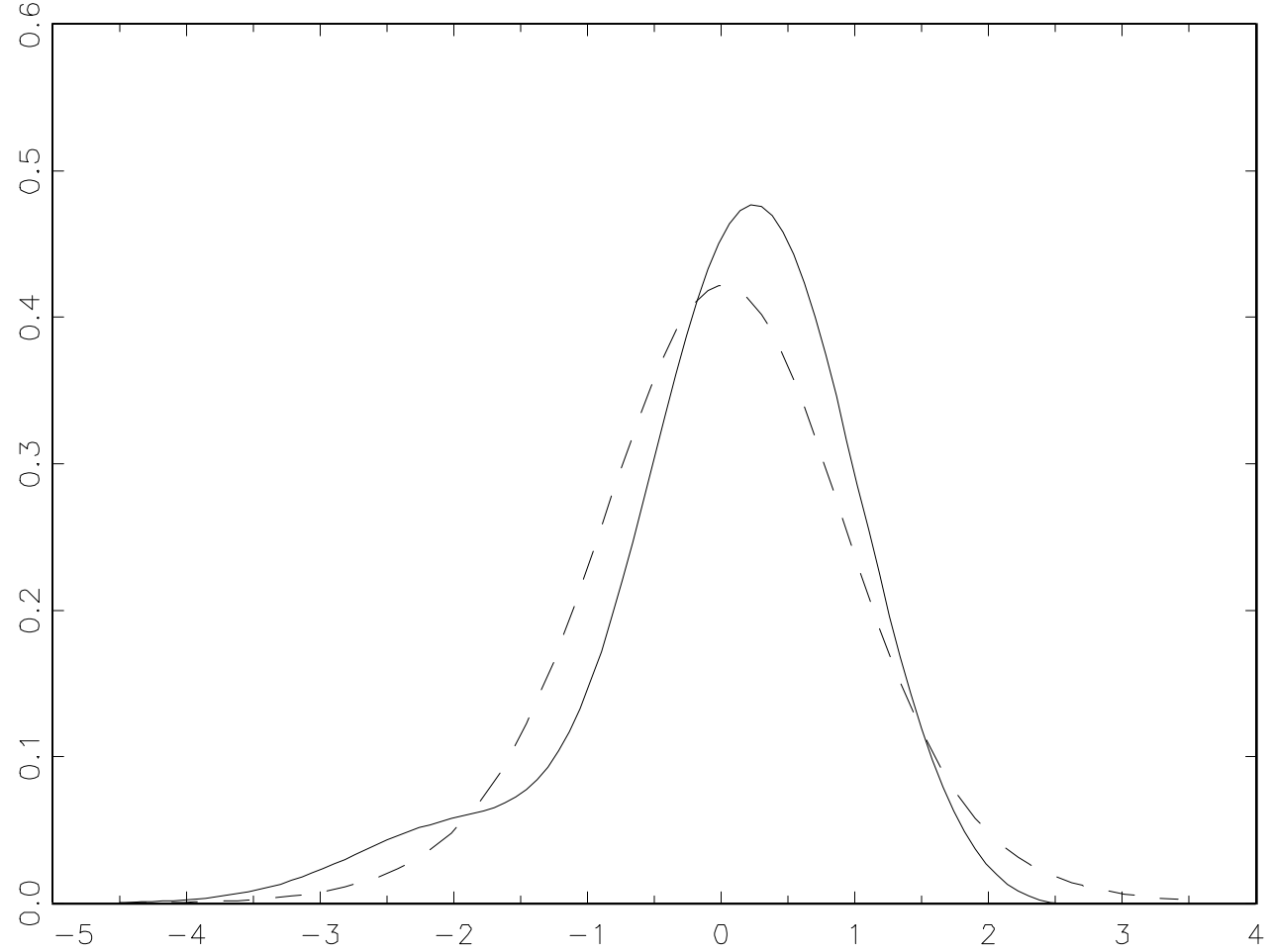

Figure 3a: Density function of demand shocks

Density function of supply shocks

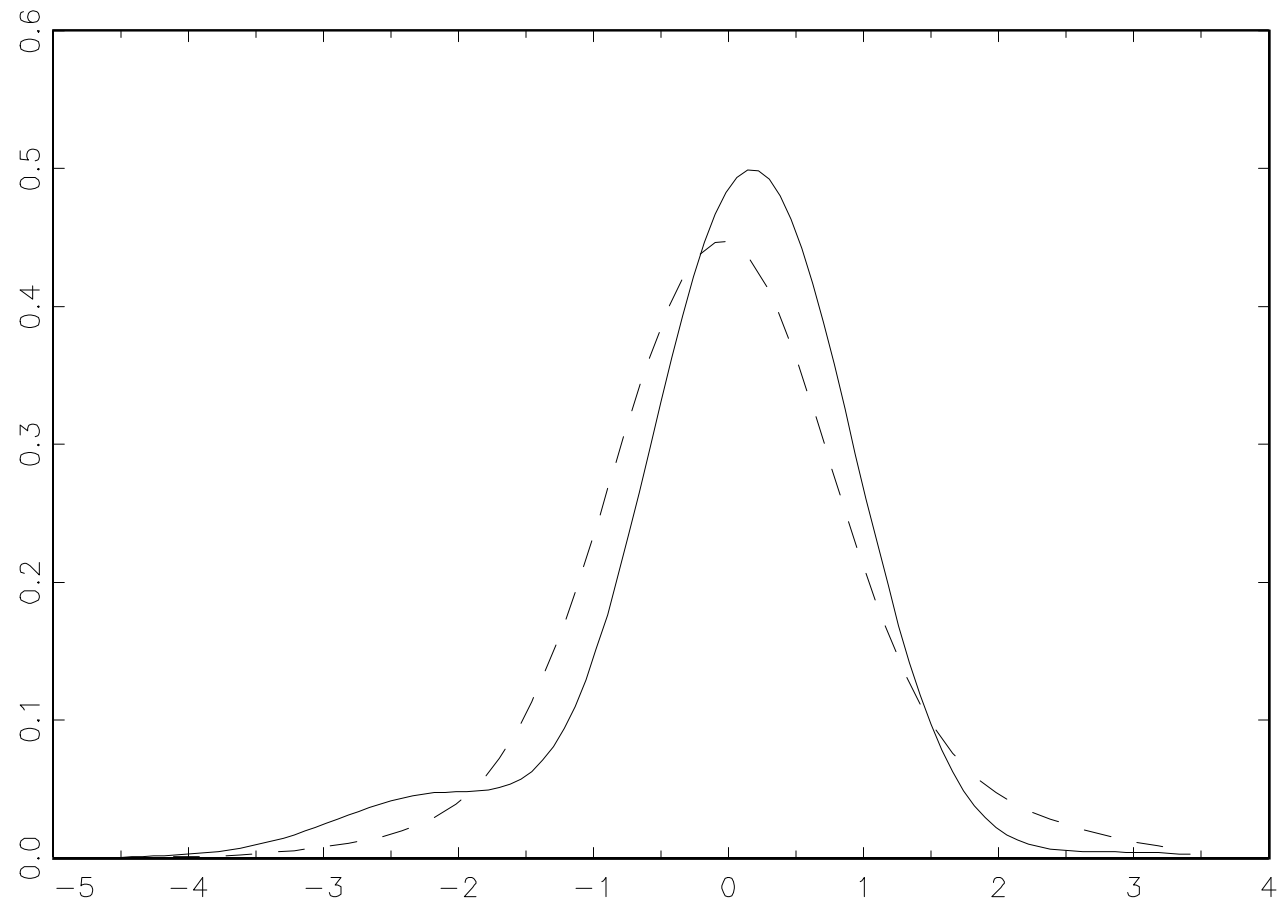

Figure 3b: Density function of supply shocks

Solid line $=$ Free float period, Dashed line $=$ currency board period 


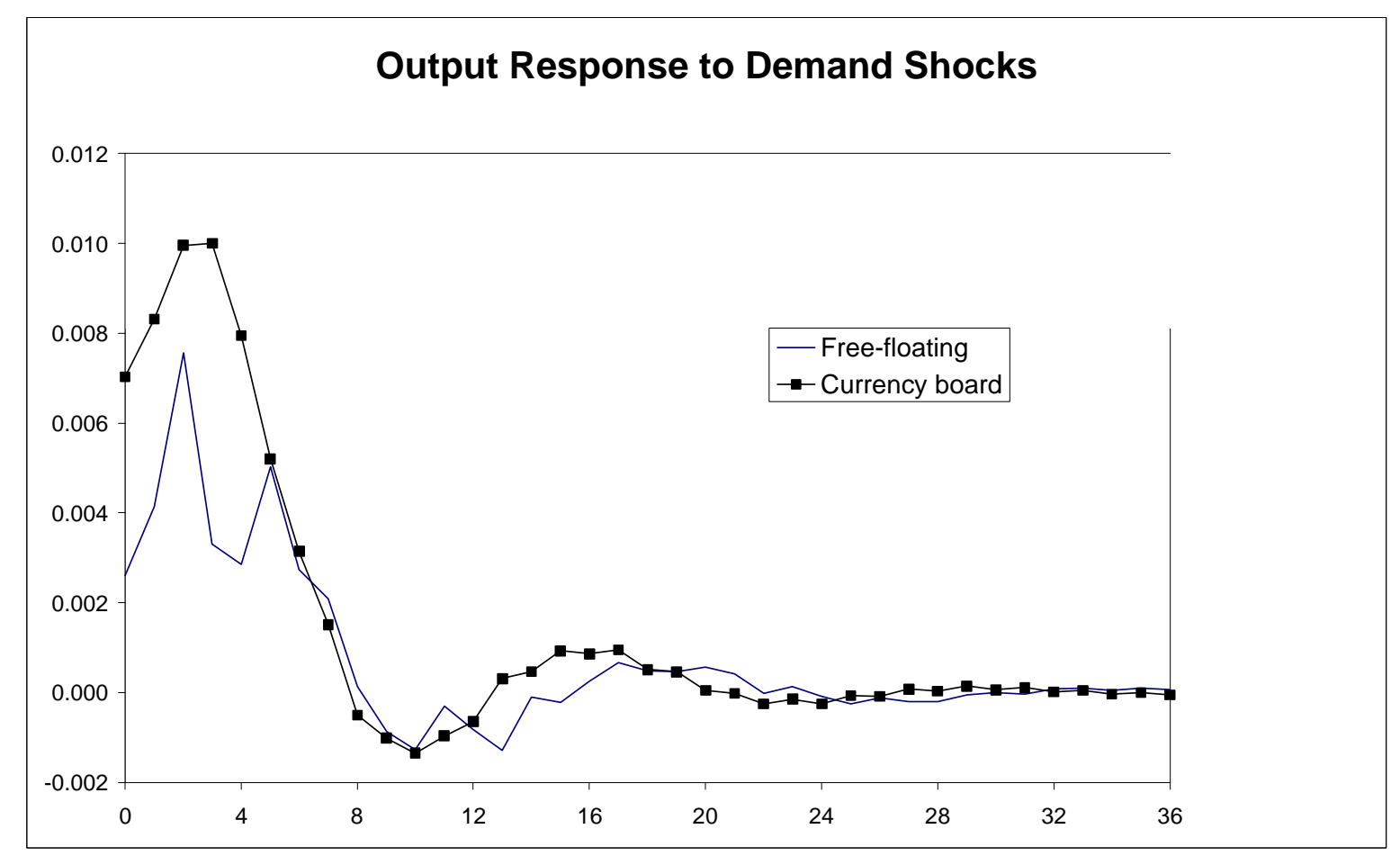

Figure 4a

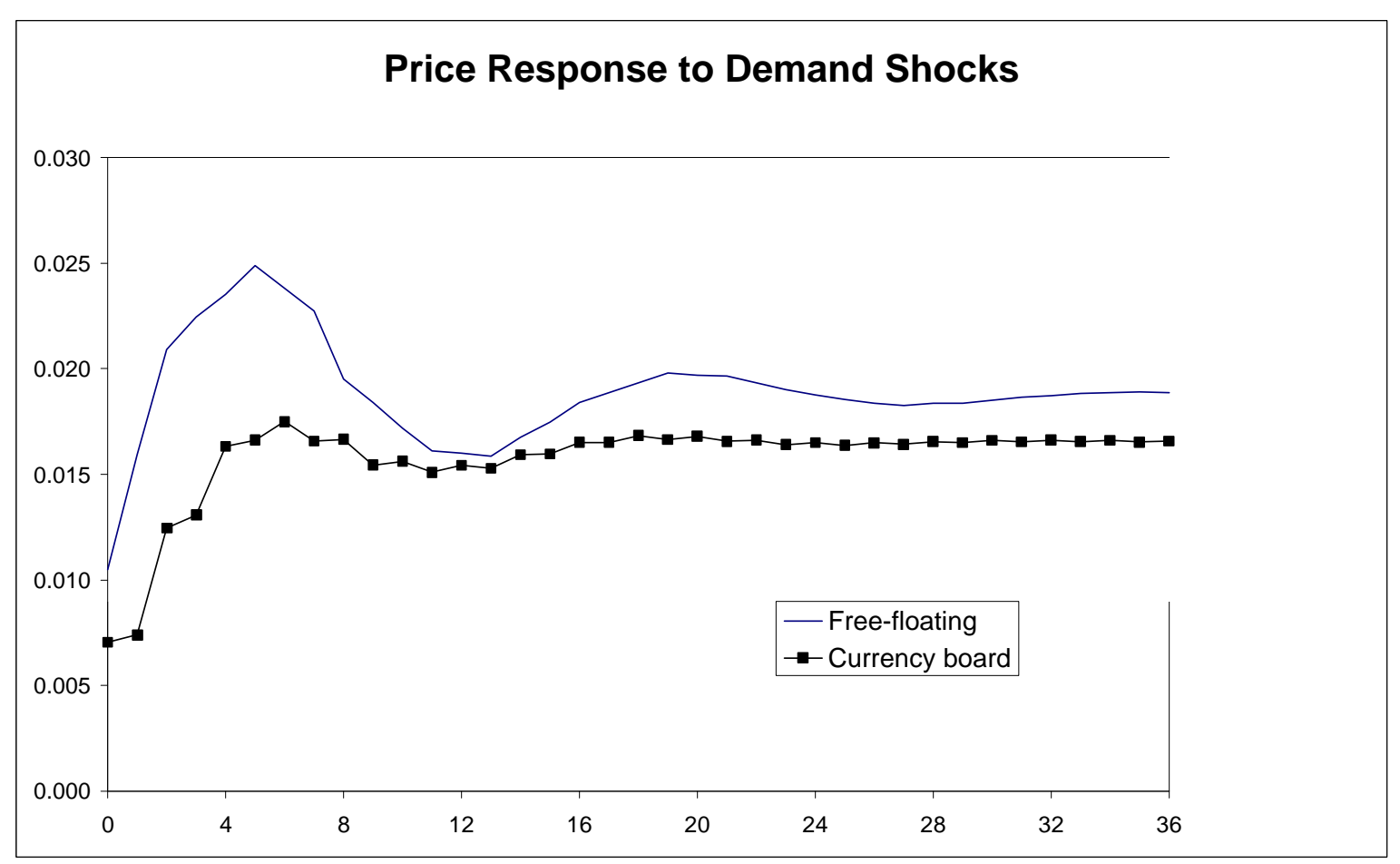

Figure 4b 


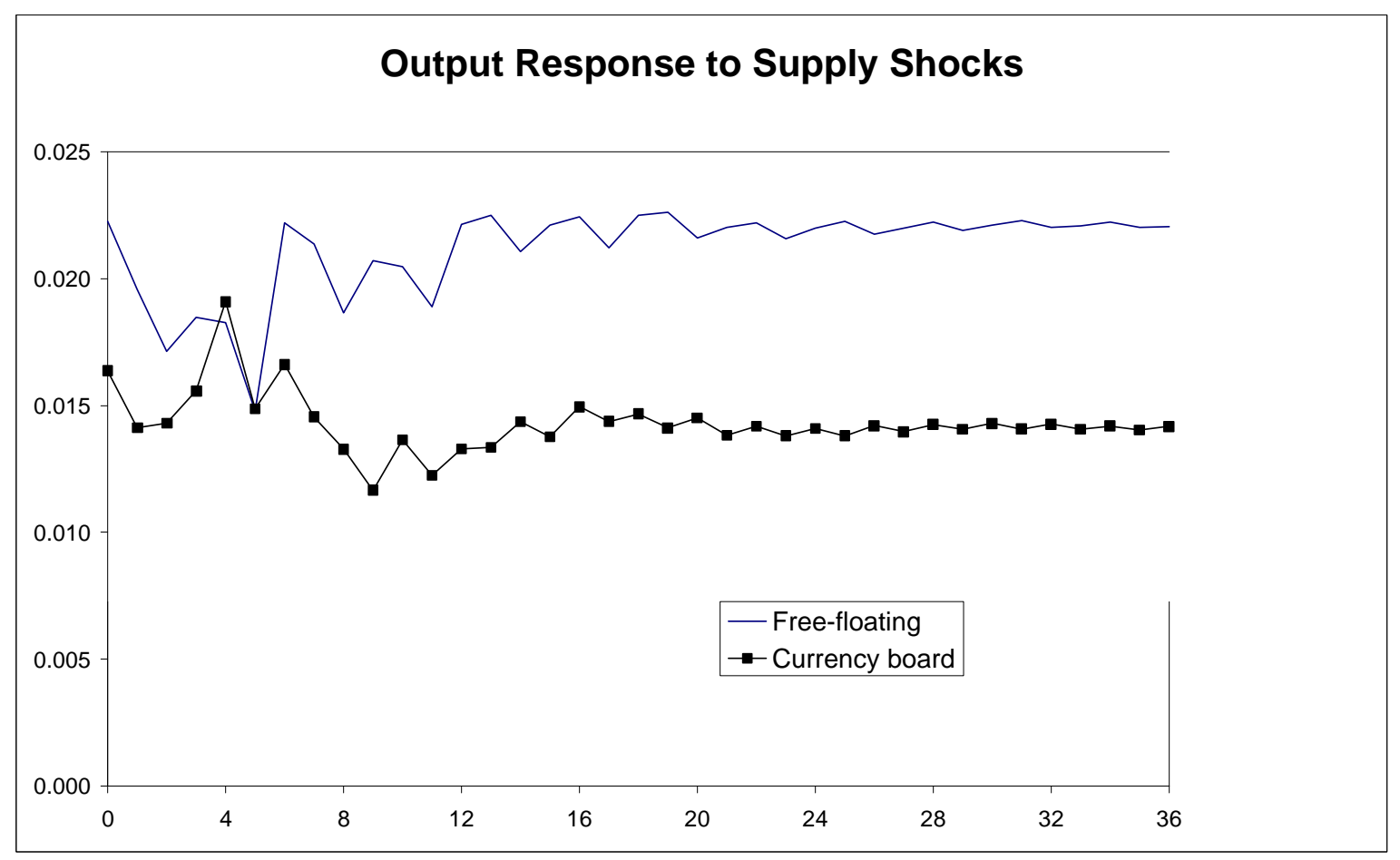

Figure 5a

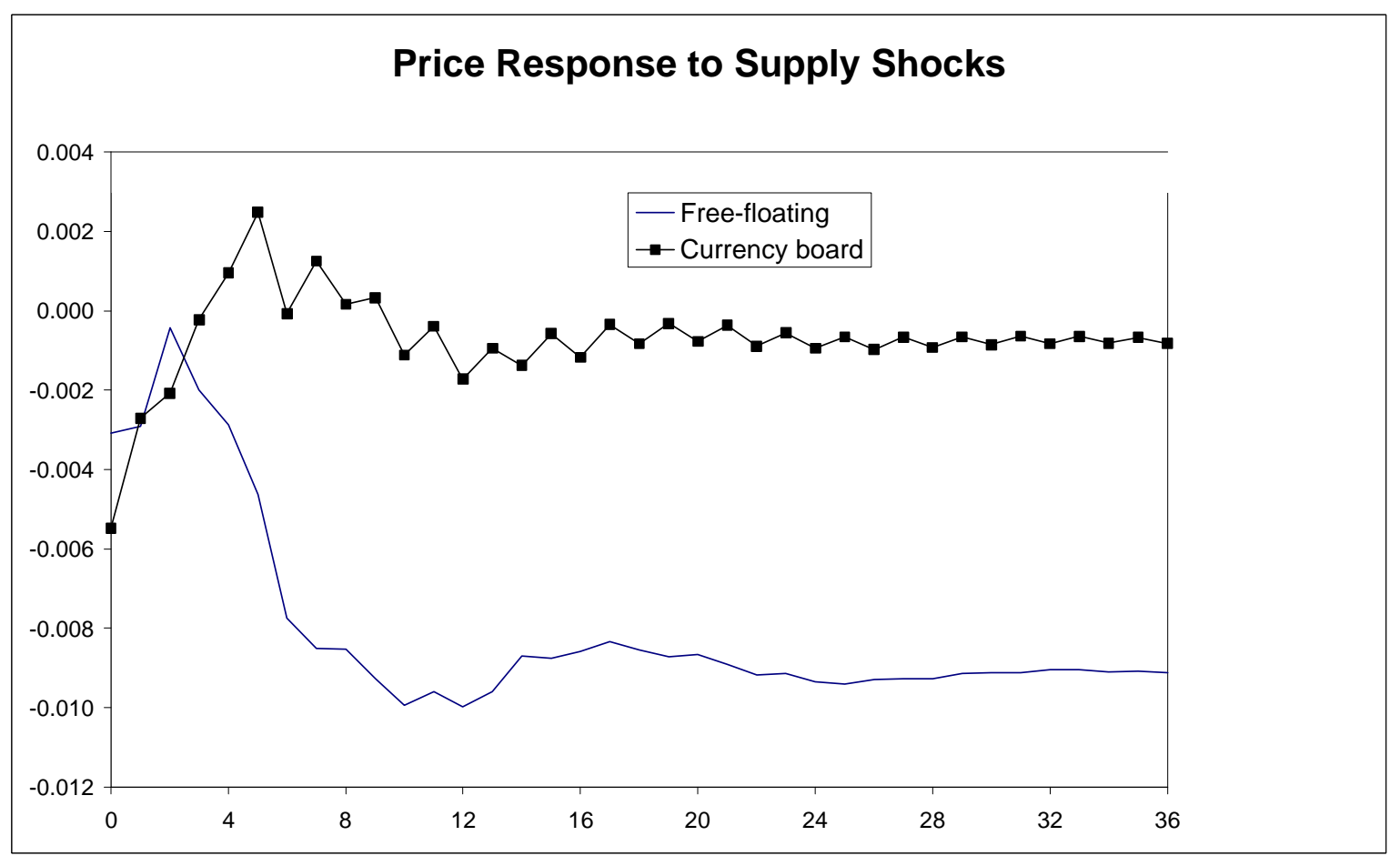

Figure 5b 


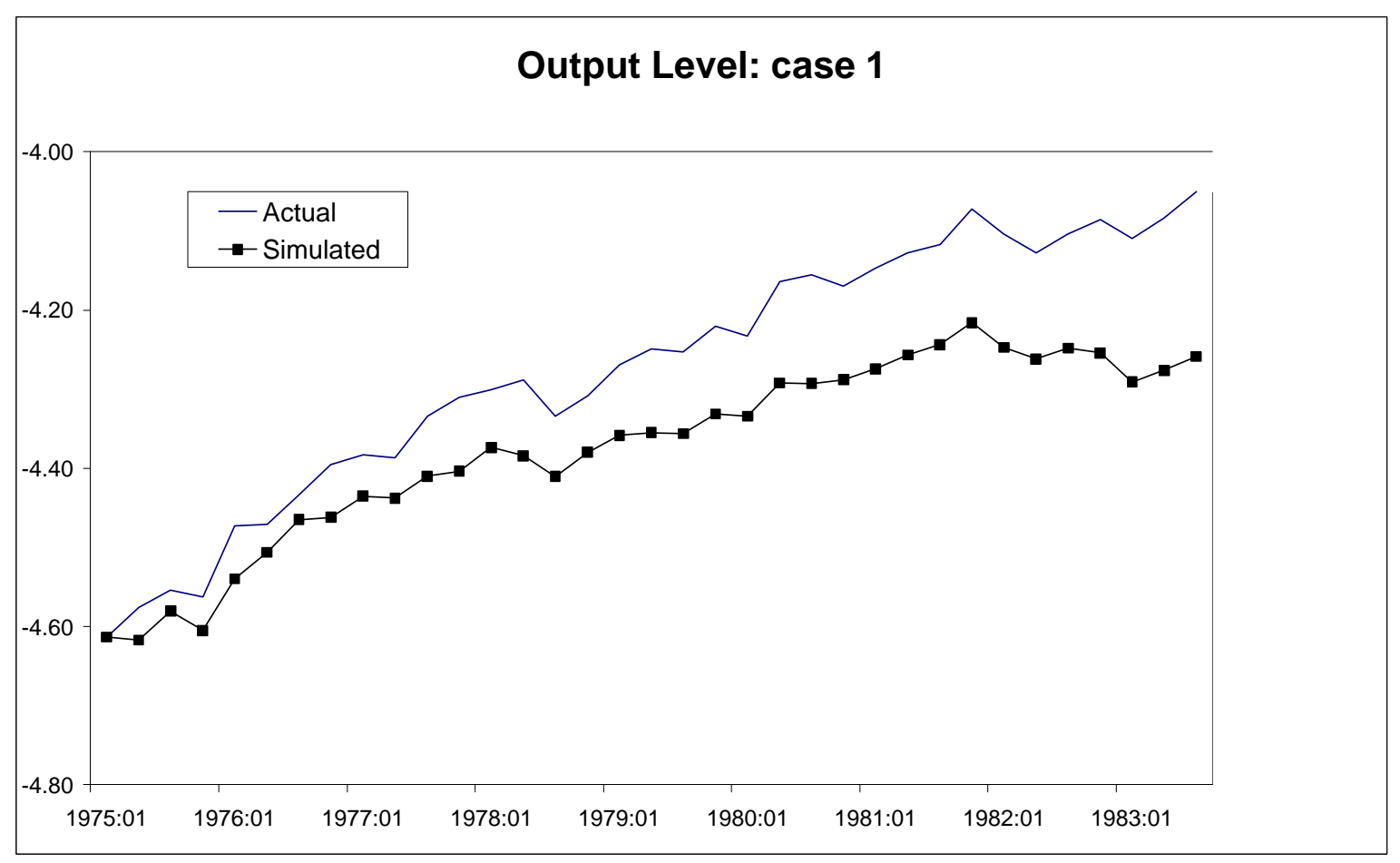

Figure 6a

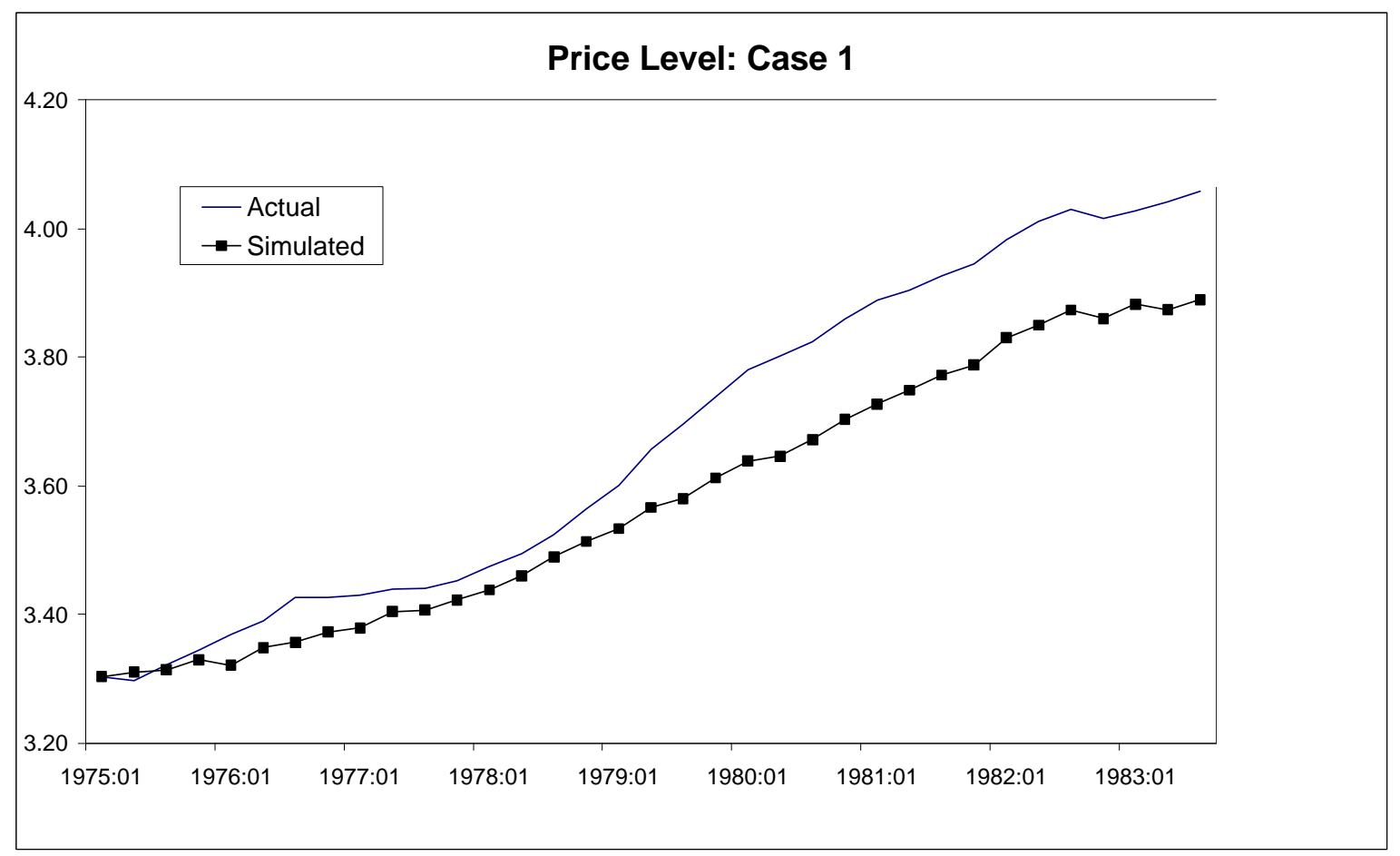

Figure 6b 


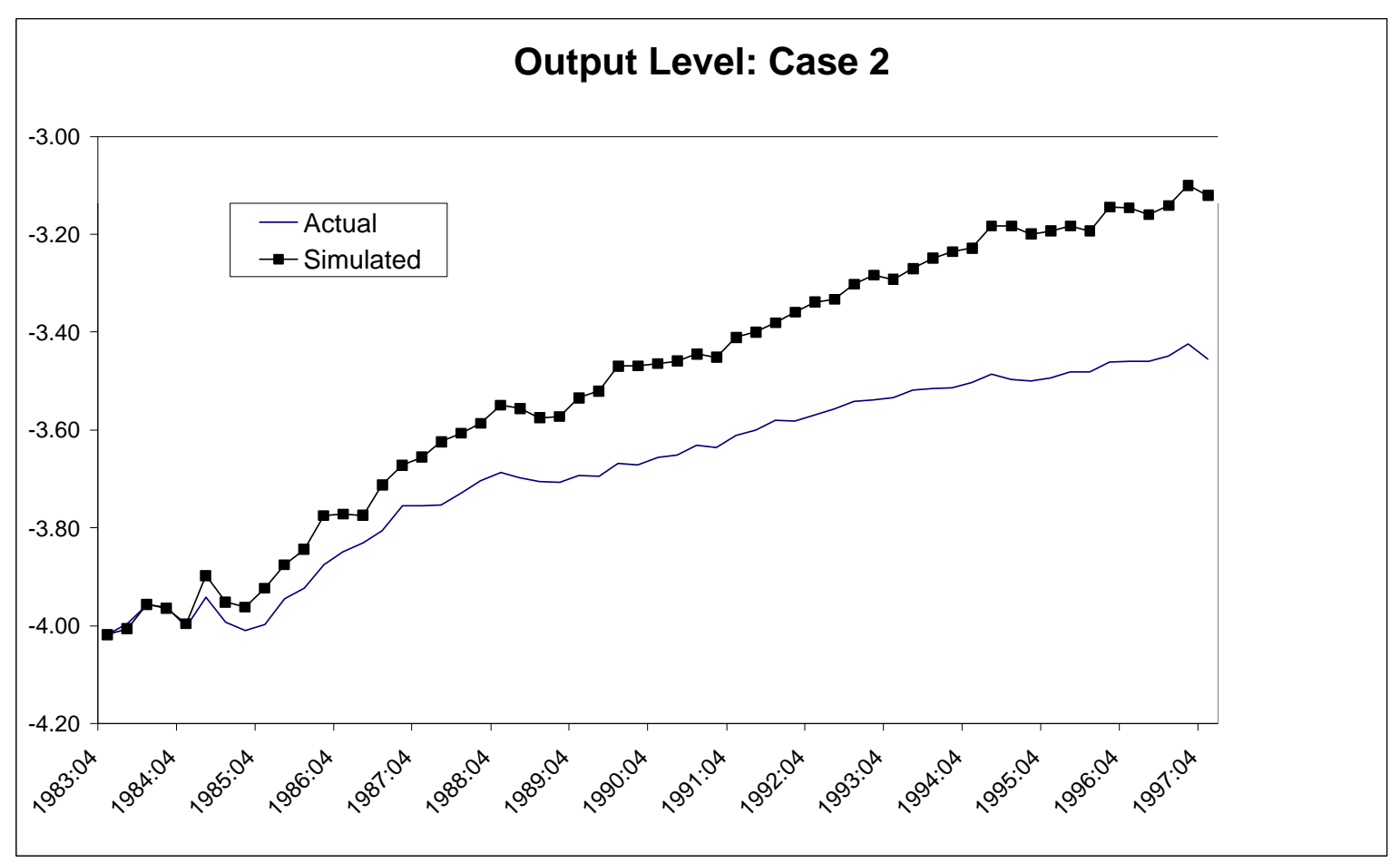

Figure 7a

\section{Price Level: Case 2}

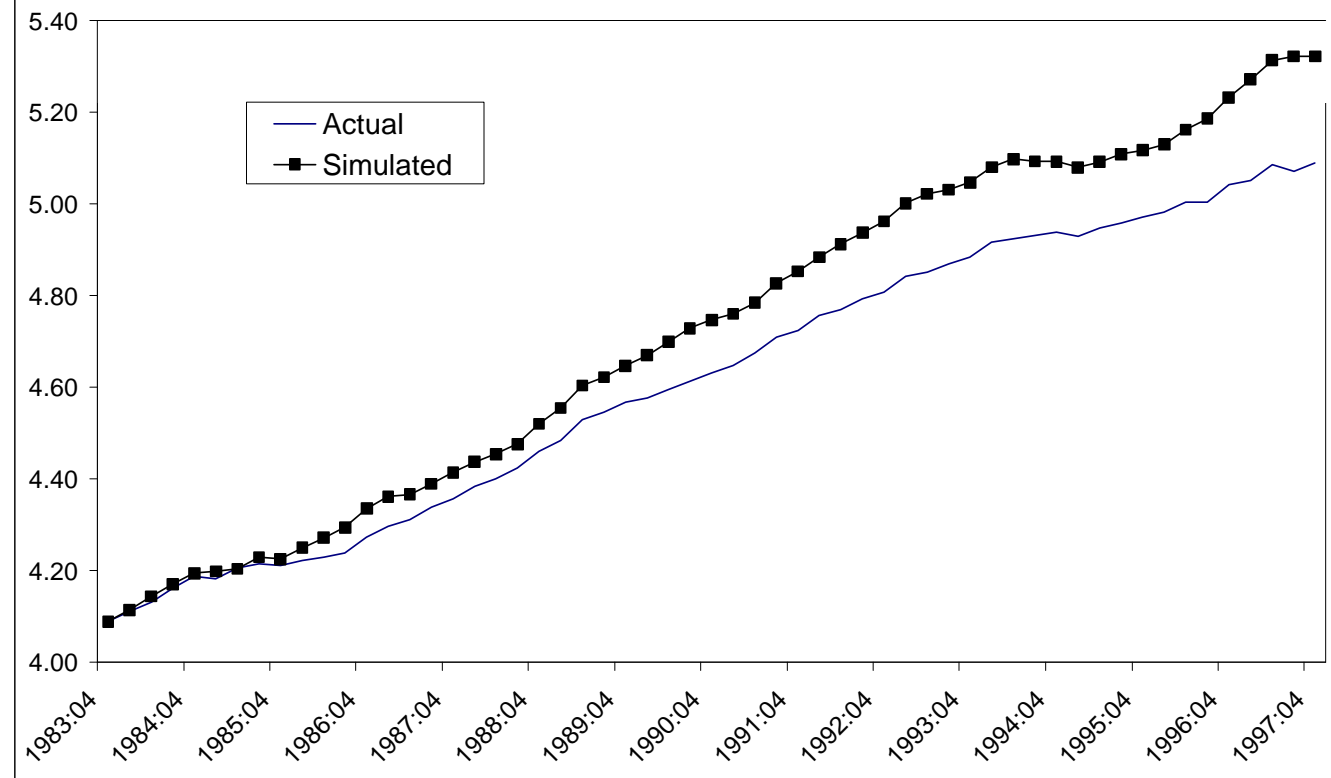

Figure 7b 